\title{
Frequency of Cyclonic Disturbances and Changing Productivity Patterns in the North Indian Ocean Region: A Study Using Sea Surface Temperature and Ocean Colour Data
}

\author{
Madhumita Tripathy, Mini Raman, Rashmin Dwivedi, Ajai \\ Marine, Planetary, Earth Science Group, Space Applications Centre (ISRO), Ahmedabad, India \\ Email: tmadhumita@sac.isro.gov.in
}

Received December 14, 2011; revised March 5, 2012; accepted April 6, 2012

\begin{abstract}
In recent years we are observing devastating cyclones like Nargis, Gonu, Sidr, Liala, Phet etc in the North Indian Ocean associated with heavy rains, thunderstorm, high tide and intense winds that caused shocking destructions in the coastal areas. As these are originating over the Ocean and propagating towards land, they also change physical property as well as biological structure of the Ocean. In recent years, several attempts were made to associate tropical cyclone trends with climate change resulting from green house warming. The studies have indicated an increase in intense cyclones in the Arabian Sea. Time series analysis of ocean colour data have revealed rapid and profound change in the productivity pattern over the last few years in the Arabian Sea that appears to be related to the warming trends being experienced over the Asian subcontinent. In view of the above, a study was carried out to examine the frequency of cyclonic disturbances in the Arabian Sea and the Bay of Bengal and its effect in modulating the productivity patterns. Data on the monthly and annual occurrences of tropical cyclones in the Bay of Bengal and the Arabian Sea were collected from 1908 to 2007 from SAARC Meteorological Research Centre and Indian Meteorological Department. Sea surface temperature (SST) from NOAA-AVHRR and phytoplankton biomass indexed as chlorophyll-a concentration from Sea WiFs for ten years (1998-2007) were used to study the physical and biological effects of cyclonic events in the Arabian Sea (AS) and the Bay of Bengal (BOB). Analysis of the monthly and annual occurrences of tropical cyclone reveals an increasing trend of cyclonic disturbances in the AS whereas there is a decreasing trend in the $\mathrm{BOB}$ in the last decade (1998-2007). SST analysis indicates decrease in monthly average SST by $1.5^{\circ} \mathrm{C}$ to $1.75^{\circ} \mathrm{C}$ in the AS and $1.5^{\circ} \mathrm{C}$ to $1.25^{\circ} \mathrm{C}$ in the BOB in the pre-monsoon season. Phytoplankton biomass was observed to increase by a factor of two after the passage of cyclone. Results of the ten year analysis and comparison with the climatology showed that frequent occurrence of cyclonic events that cause short term-nutrient enrichment of upper-stratified ocean resulting in enhanced biological productivity and perturbations in the otherwise stable and seasonally-varying ecological structure of the North Indian Ocean.
\end{abstract}

Keywords: Cyclonic Events; Arabian Sea; Bay of Bengal; SST; Chlorophyll-a; Ecological Structure.

\section{Introduction and Background}

Cyclonic events are characterized by a low-pressure center and numerous thunderstorms. In tropical north Indian Ocean while cyclones are known as tropical cyclones, in North Atlantic Ocean and northwestern Pacific Ocean they are known as hurricanes and typhoons. There are six favorable conditions for cyclogenesis [1]. Sea surface temperature (SST) is one of most important factor for development of cyclones. Tropical Ocean SSTs increased by approximately $0.5^{\circ} \mathrm{C}$ between 1970 and 2004 [2]. This significant increase in SST is thought to be due to increase in greenhouse gasses like carbon dioxide, methane, nitrous oxide [3]. Ocean plays an important role in carbon cycle through physical, chemical and biological process. Through the process of photosynthesis phytoplankton converts inorganic to organic carbon and removes carbon-dioxide from atmosphere. Thus change in phytoplankton growth and community will affect carbon dynamics. Phytoplankton growth depends on sunlight, availability of nutrients and temperature. In the tropical region where sufficient amount of sunlight is available throughout the year, phytoplankton blooms occur mainly by cold nutrients rich water is coming from deep to the surface through upwelling or convective mixing.

Arabian Sea (AS) and Bay of Bengal (BOB) are two 
basins in North Indian Ocean. Though AS and BOB are landlocked to the north, they show large contrast in salinity, SST and even productivity pattern [4]. Both the basins are influenced by south westerly wind in summer and north easterly in wind in winter season. Rather than monsoonal wind very high intense but short duration cyclonic winds are frequent in both the basins. There are increase in occurrences of intense cyclones in AS [5,6] as well as in all of the world basin [7] and change of oceanic property was observed after cyclone travel [8-14]. Remote sensing is a useful tool in mapping chlorophyll-a distribution in spatial and temporal scale. Different ocean color sensors: OCTS, POLDER, MOS, SeaWiFS, OCM, MODIS-AM, MISR, OCI, OSMI, GLI, PolDER-2, MODIS-PM etc. are operated to fulfill the purpose. With unique spiral shape and central eye, the tropical cyclones are memorable features on any satellite image. IMD (Indian Meteorological Department) reported the intensity, wind speed, positions etc. of the different stages of cyclonic disturbances in the BOB and AS with the help of convention surface and upper air observations, coastal automatic weather station (AWS), ships and buoy observations, cyclone detection radar (Doppler weather radar) and satellite cloud pictures from the polar orbiting meteorological satellites and the geo-stationary satellites (INSAT 3A \& Kalpana 1).

In this paper, we discuss the frequency of cyclonic disturbances in the AS and the BOB using 100 years data from 1908 to 2007 and its effect in modulating the changing productivity pattern using daily and monthly data of Sea surface temperature (SST) from NOAAAVHRR and phytoplankton biomass indexed as chlorophyll-a concentration from SeaWiFs for ten years (1998-2007) in the pre-monsoon and post-monsoon season in the open ocean. We have also discussed the comparison of the effect between the AS and the BOB. This paper demonstrates that frequent occurrence of cyclonic events causes short term-nutrient enrichment of upper-stratified ocean resulting in enhanced biological productivity and perturbations in the otherwise stable and seasonally-varying ecological structure can bring longterm shift in average weather conditions and ecological structure of the North Indian Ocean.

\section{Datasets and Methodology}

\subsection{Cyclonic Disturbances Data}

The monthly and annual occurrences of tropical cyclones in BOB $\left(-10^{\circ} \mathrm{S}\right.$ to $32^{\circ} \mathrm{E}, 78^{\circ} \mathrm{E}$ to $\left.110^{\circ} \mathrm{E}\right)$ and $\mathrm{AS}\left(-10^{\circ} \mathrm{S}\right.$ to $32^{\circ} \mathrm{E}, 32^{\circ} \mathrm{E}$ to $78^{\circ} \mathrm{E}$ ) in winter monsoon (DJFM), premonsoon (AM) summer monsoon (JJAS), and post monsoon (ON) season were collected from 1908 to 1996 from SAARC Meteorological Research Centre (SMRC) publication No. 1 [15] and from 1997 to 2007 from
Mausam journal published by IMD [16-26]. The information about the path traveled by cyclonic disturbances was obtained also during 1998 to 2007 in pre-monsoon and post-monsoon season from Mausam journal [17-26]. Cyclonic disturbances data are categorized into Low pressure (L), Depression (D), Deep Depression (DD), Cyclonic Storm (CS), Severe Cyclonic Storm (SCS), Very Severe Cyclonic Storm (VSCS) and Super Cyclone Storm on the basis of 10 minutes sustained wind speed (criteria by IMD) [15-26]. Analysis for the study: Annual frequency of 100 years data of tropical cyclone are tabulated and pooled on a decadal scale in Indian Ocean Region. 1997-2006, 1987-1996, 1977-1986, 1967-1976, 1957-1966, 1947-1956, 1937-1946, 1927-1936, $1917-$ 926, 1907-1916 decades are used. Mean of the tropical cyclone occurrence in each decade was calculated.

\subsection{Bathymetry Data}

The bathymetry image was generated using a gridded data obtained from ETOPO5. The gridded data is in 30 minutes resolution. The cyclonic disturbances in open ocean $(>500 \mathrm{mt})$ were taken for study.

\subsection{SST and Chlorophyll-a Data}

The Global daily and monthly data of NOAA-AVHRR daytime SST of $4 \mathrm{~km}$ resolution and SeaWiFs chlorophyll-a of $9 \mathrm{~km}$ resolution were obtained from 1998 to 2007 from ftp://podaac.jpl.nasa.gov and http://oceancolor. gsfc.nasa.gov.

The version of NOAA-AVHRR SST was pathfinder version 5. It was a new reanalysis of the AVHRR data stream using multi-channel sea surface temperature algorithm developed by Rosensiel School of marine and Atmospheric Science (RSMAS) and the NOAA National Oceanographic Data Centre. Methods involved generating radiance images from raw data using calibration coefficients obtained from header file and generating brightness temperature using Plank's law and McClain's split enhanced algorithm for computing SST. Processing steps produced twice daily global SST. Monthly data was produced by temporal averages of daily data.

Level-3 binned file format was used for SeaWiFs chlorophyll-a. The ocean colour algorithm OC4V5, a four band $(443,490,510,555)$, maximum band ratio proposed by O'Reilly et al. [27] was used to compute chlorophyll-a concentration.

Analysis for the study: Subset for BOB $\left(-10^{\circ} \mathrm{S}\right.$ to $32^{\circ} \mathrm{N}$, $78^{\circ} \mathrm{E}$ to $\left.110^{\circ} \mathrm{E}\right)$ and $\mathrm{AS}\left(-10^{\circ} \mathrm{S}\right.$ to $32^{\circ} \mathrm{N}, 32^{\circ} \mathrm{E}$ to $\left.78^{\circ} \mathrm{E}\right)$ was generated. For each of the images of SST and chlorophyll images square grids having a resolution of 0.225 degrees $(25 \mathrm{~km} \times 25 \mathrm{~km})$ were generated for analysis and the corresponding bathymetry grids were also generated. The grids were generated using the vector module in 
ERDAS IMAGINE of version 9.1 and the minimum, maximum, mean and standard deviation of the SST and chlorophyll images were estimated for each grid.

Generation of SST and chlorophyll-a climatology image: Monthly climatology of SST and chlorophyll-a was prepared averaging each square grid of resolution 0.225 degree from 1998 to 2007. Standard deviation was also calculated. The range of standard deviation was within \pm 1 .

Daily Analysis: $4 \mathrm{~km} \mathrm{SST} \mathrm{images} \mathrm{were} \mathrm{degraded} \mathrm{to} 9$ $\mathrm{km}$ SST image using degrade module of ERDAS IMAGINE. Then pixel basis analysis was done then with both $9 \mathrm{~km}$ SST and $9 \mathrm{~km}$ chlorophyll-a image.

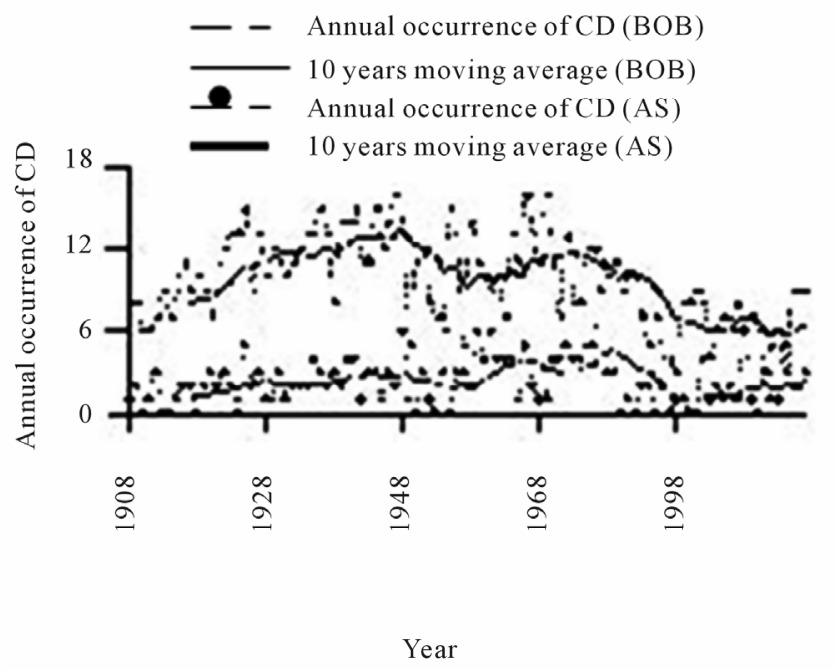

(a)

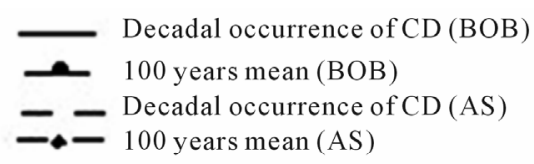

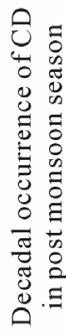

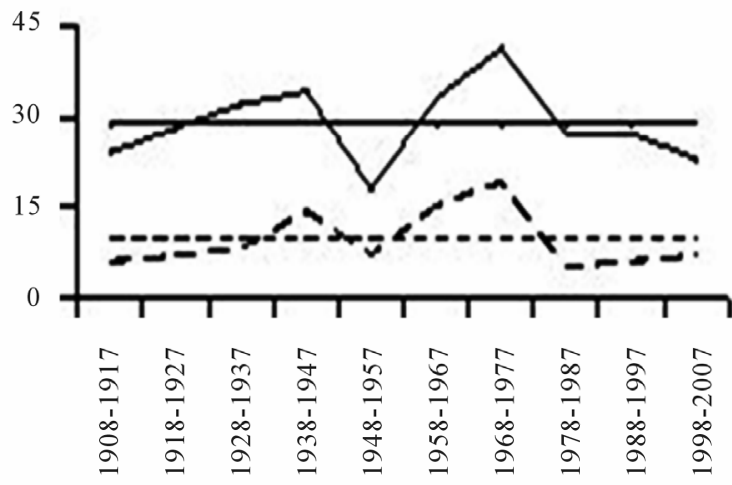

Decade

(c)

\section{Results}

\subsection{The Occurrence of Cyclonic Disturbances (CD) in the BOB and AS}

Annual and decadal occurrence of cyclonic disturbances (CD) in the BOB and AS during 1908 to 2007 is shown in Figure 1.

The decadal variation shows that in the BOB there were two complete cycles consisting (1908 to 1957) period and (1957 to 1987) period. But 1908 to 1957 period in AS did not show remarkable variation and another period 1957 to 1987 in both AS and BOB showed the same type of trend. But after 1987 BOB showed the decreasing

$$
\begin{aligned}
& \text { ــ Decadal occurrence of CD (BOB) } \\
& \text { ـ } 100 \text { years mean (BOB) } \\
& \text { - Decadal occurrence of CD (AS) } \\
& \square-100 \text { years mean (AS) }
\end{aligned}
$$
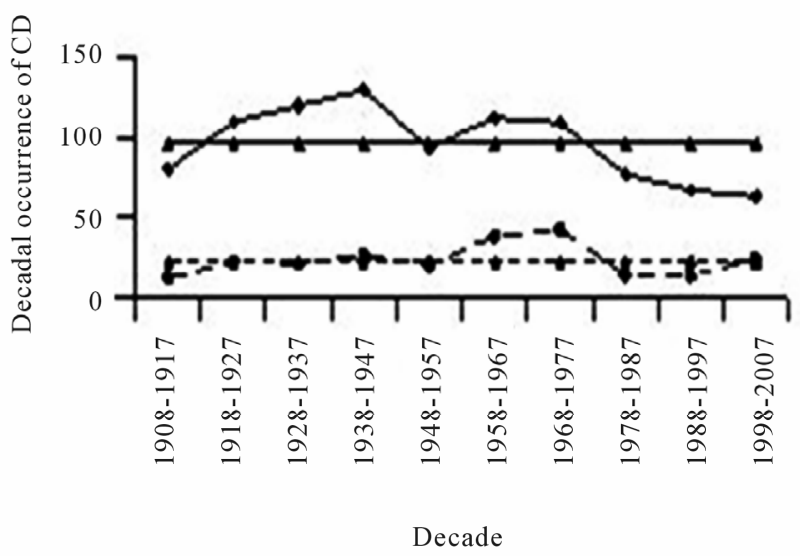

(b)

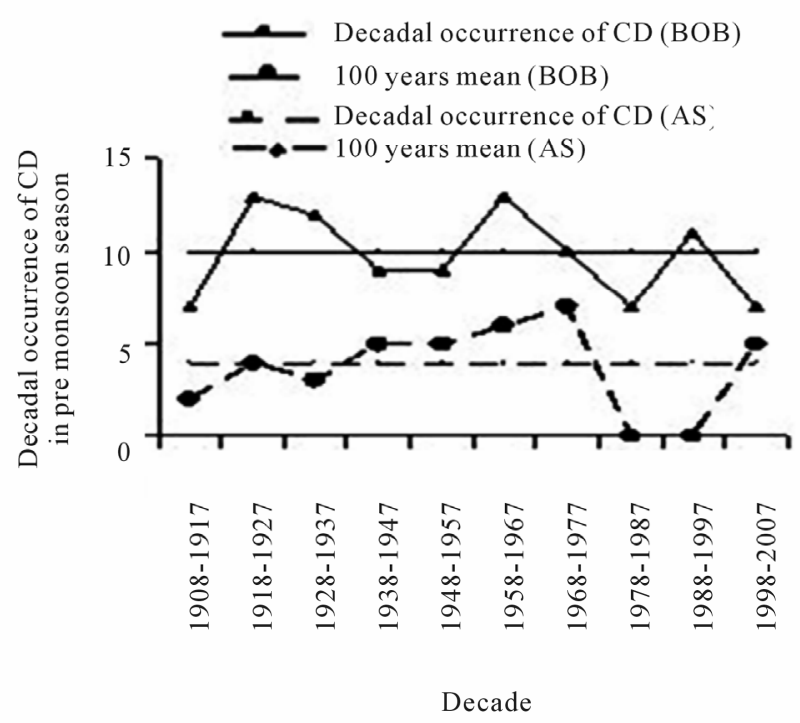

(d)

Figure 1. (a) Annual occurrence of cyclonic disturbances in the BOB and AS during 1908 to 2007; (b) Decadal occurrence of cyclonic disturbances in the AS and BOB; (c) Decadal occurrence of cyclonic disturbances in the AS and BOB in the post monsoon season; (d) Decadal occurrence of cyclonic disturbances in the AS and BOB in the pre-monsoon season. 
trend and AS showed the increasing trend.

The post monsoon decadal variation of both $\mathrm{BOB}$ and AS showed same cyclic pattern up to 1987 and from 1988 to 2007 the increasing trend was observed in the AS whereas BOB did not show.

In pre-monsoon season AS showed continuous increasing trend up to 1977 and from 1978 to 1997 there were no cyclonic disturbances, but the present decade during 1998 to 2007 showed increasing trend and also it was $25 \%$ more than 100 years mean of occurrence of CD whereas cyclic pattern in occurrence of CD consisting (1908 to 1947), (1948 to 1987) and (1987 to 2007) periods were observed in the BOB in the pre-monsoon season.

\subsection{Climatology of SST and Chlorophyll-a for Premonsoon Season (April and May) and Post Monsoon (October, November) Season in the Bay of Bengal and Arabian}

SST and chlorophyll climatology for April, May and October, November during 1998 to 2007 period is shown in Figures 2(a) and (b).

Northern AS SST was from $28.5^{\circ} \mathrm{C}$ to $29^{\circ} \mathrm{C}$ whereas BOB SST was from $29.5^{\circ} \mathrm{C}$ to $30.2^{\circ} \mathrm{C}$ during May month. SST variation was from $29.5^{\circ} \mathrm{C}$ to $30^{\circ} \mathrm{C}$ in northern $\mathrm{BOB}$ whereas; SST variation was from $28.5^{\circ} \mathrm{C}$ to $29.4^{\circ} \mathrm{C}$ in the northern AS in October month. SST was lower in November month compared to that in October month in the northern Indian Ocean.

Chlorophyll ranged in the open ocean in the AS was from 0.1 to $0.19 \mathrm{mg} / \mathrm{m}^{3}$ in April month. Above $20^{\circ} \mathrm{N}$ latitude $0.45-0.8 \mathrm{mg} / \mathrm{m}^{3}$ chlorophyll was observed in the north AS. In central BOB $0.1-0.15 \mathrm{mg} / \mathrm{m}^{3}$ chlorophyll-a variation was observed.

Chlorophyll-a variation was observed from 0.1 to 0.16 $\mathrm{mg} / \mathrm{m}^{3}$ in the AS and from 0.1 to $0.15 \mathrm{mg} / \mathrm{m}^{3}$ in the BOB in May month in the open Ocean. Higher value of chlorophyll-a in a range $0.4-0.8 \mathrm{mg} / \mathrm{m}^{3}$ was observed in May in the $20^{\circ} \mathrm{N}$ around Srilanka and around Oman coast from $2^{\circ} \mathrm{N}-10^{\circ} \mathrm{N}$ latitude in the Arabian Sea. In post monsoon period chlorophyll-a concentration from 0.15 to $0.25 \mathrm{mg} / \mathrm{m}^{3}$ was observed in the open ocean in the BOB. Western AS showed high chlorophyll-a from $0.5 \mathrm{mg} / \mathrm{m}^{3}$ to $1 \mathrm{mg} / \mathrm{m}^{3}$ in the post monsoon period.

\subsection{The Occurrence, Path, Duration of Different Category of Cyclonic Disturbances (CD) during 10 Years (1998-2007) Period}

During the study period from 1998 to 2007 CD which were occurred in the AS and $\mathrm{BOB}$ in the pre-monsoon season are shown in Figure 3.

Among the five $\mathrm{CD}$ in the AS in the pre-monsoon season, there were two VSCS in 1999 and 2001 and two
SCS in 2002 and 2004 [18,20,21,23]. In 1998 there were a DD on 28 May 1998 in east-central AS, but it did not turn into CS [17]. On 15 May 1999 a well-marked lowpressure area formed adjoining north Kerala coast and intensified into D, CS, SCS and VSCS and crossed Pakistan coast on 20 May 1999 [18]. During 21-28 May 2001, low-pressure area formed over southern parts of central Arabian Sea intensified into VSCS on 22 May 2001 but after that it weakened and on 28 May 2001 it turned into depression and dissipated in the Sea [20]. Between the two SCS on 2002 and 2004, SCS (6-10 May 2002) crossed Arabia coast and SCS (5-10 May 2004) dissipated off Saurashtra coast [21,23].

Among the seven cyclonic disturbances in the BOB in the pre-monsoon season during 1908 to 2007 (Figure 3), SCS (17-22 May, 1998) and CS (13-15 May, 2007) crossed Bangladesh coast, VSCS (10-19 May, 2003) and VSCS (16-19 May, 2004) crossed Myanmar coast and VSCS (25-29 April, 2006) crossed Arakan coast [17,22, $23,25,26$,$] . There was one DD in 2002$ May month [21] and one D in 2007 [26], which were not intensified into CS. In post monsoon season there were three SCS, two CS and two deep depression which did not turn into cyclonic storm in the Arabian Sea whereas in the Bay of Bengal there were one super cyclone in 1999, four VSCS, one SCS, five CS, nine depression and deep depression [17-26].

\subsection{The Effects of Different Category of Cyclonic Disturbances (CD) in Monthly SST and Chlorophyll-a Distribution from Climatology}

\subsubsection{Pre-Monsoon Season in the Arabian Sea}

\subsubsection{Very Severe Cyclonic Storm (VSCS) Variation in SST field}

The SST variation along the storm track of VSCS of May 1999, 10 years May climatology and different noncyclonic May month $(2003,2005,2006)$ is shown in Figure 4. Climatology May SST varied from $28.5^{\circ} \mathrm{C}$ to $30.11^{\circ} \mathrm{C}$ along the storm track. There were no cyclonic disturbances in pre-monsoon season in 2000, 2003, 2005, 2006, 2007 [19,22,24-26]. May SST 1999 variation along the cyclone track was much lower than May SST climatology and non-cyclonic May month also. Lowering of SST in 1999 was much lower than standard deviation range obtained from the 10-year climatology. Maximum lowering of SST was $0.5^{\circ} \mathrm{C}$ to $1.75^{\circ} \mathrm{C}$ around $14.5^{\circ} \mathrm{N}$ to $21.5^{\circ} \mathrm{N}$ latitude compared to climatology. The lowering of SST started beyond standard deviation of 10 years climatology when wind speed increased from SCS to VSCS [18].

\section{Variation in chlorophyll-a field}

The variation of chlorophyll from $0.14 \mathrm{mg} / \mathrm{m}^{3}$ to 0.27 
SST climatology
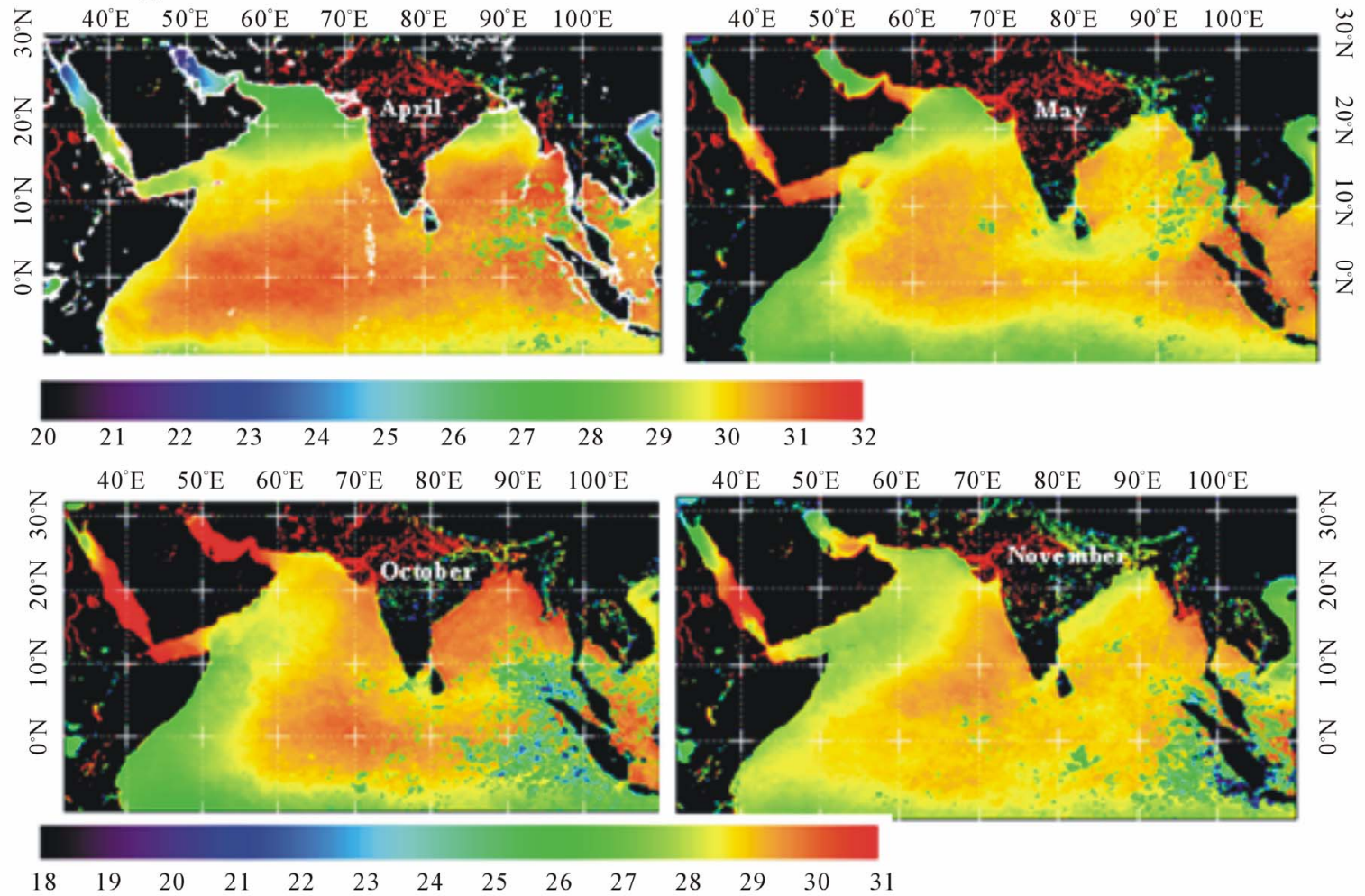

Chlorophyll climatology

(a)
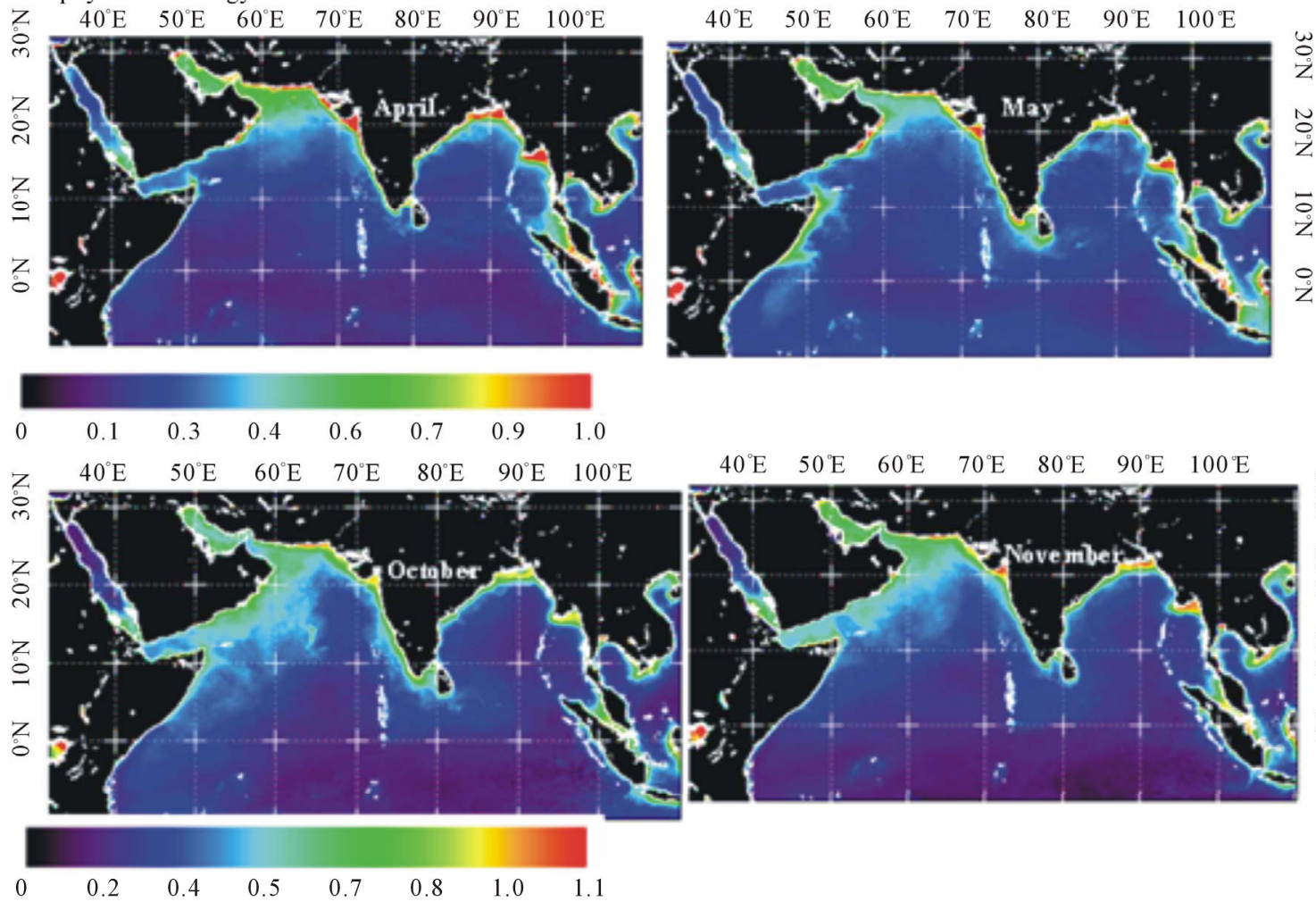

(b)

Figure 2. (a) Climatology SST variation in April, May and October, November month during 1998-2007 in the North Indian; (b) Climatology chlorophyll-a variation in April, May and October, November month during 1998-2007 in the North Indian Ocean. 

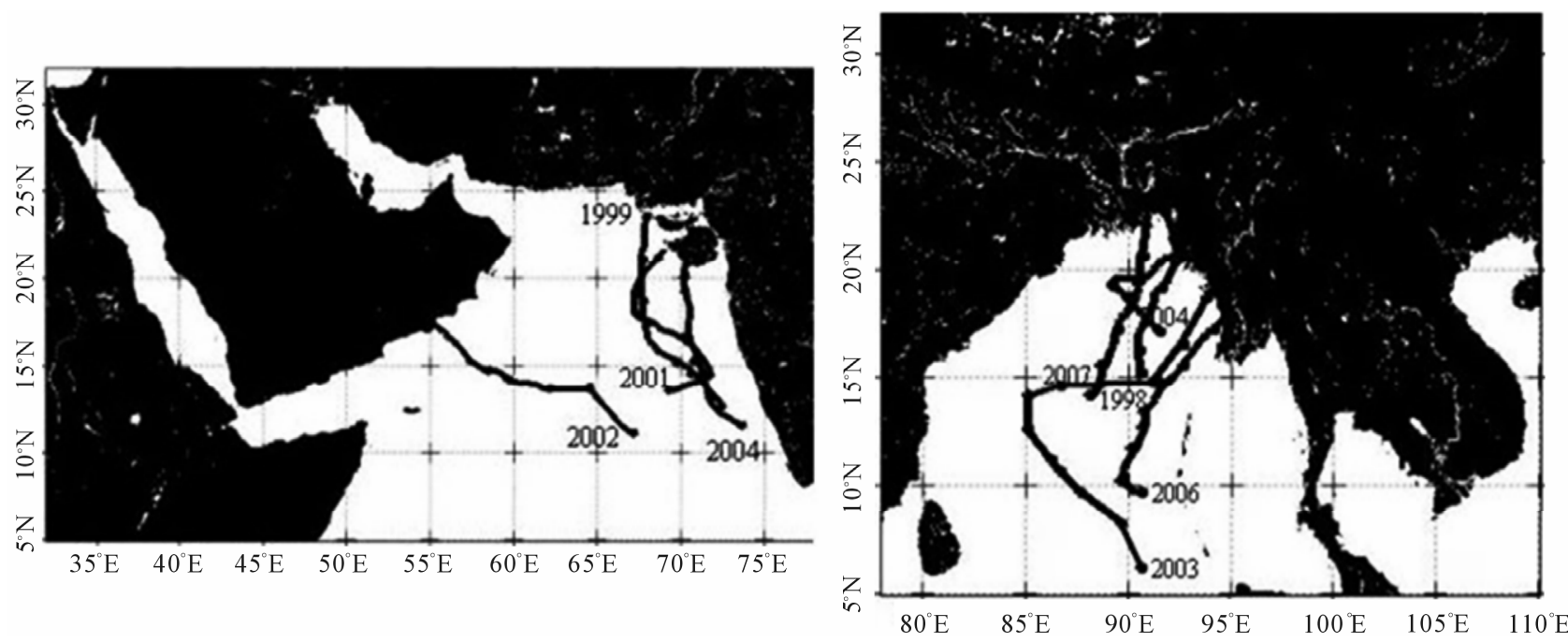

Figure 3. The tracks of tropical cyclones in the Arabian Sea and Bay of Bengal in the pre-monsoon season during 1998 to 2007.

$\mathrm{mg} / \mathrm{m}^{3}$ was observed in May chlorophyll climatology whereas in the northern AS, chlorophyll was higher compared to southern Arabian Sea along the storm track. Chlorophyll-a variation in May 1999 along the storm track was compared with 10-year climatology (Figure 4). Around $20^{\circ} \mathrm{N}$ to $22^{\circ} \mathrm{N} 150 \%$ increased chlorophyll from climatology was observed where VSCS wind speed sustained [18].

But the variation of SST and chlorophyll in May 2001 was within standard deviation of 10 years climatology.

\subsubsection{Severe Cyclonic Storm (SCS) \\ Variation in SST field}

The SST variation along the storm track in May climatology was from $29.25^{\circ} \mathrm{C}$ to $30.10^{\circ} \mathrm{C}$. Mean SST variation in May 2004 along the storm track is shown in Figure 5.

From $11.5^{\circ} \mathrm{N}$ latitude to $13.5^{\circ} \mathrm{N}$ latitude the wind speed increased from D to SCS and from $13.5^{\circ} \mathrm{N}$ to $15^{\circ} \mathrm{N}$ wind speed decreased from SCS to CS [23]. From $11.5^{\circ} \mathrm{N}$ to $16^{\circ} \mathrm{N}$ around $495 \mathrm{~km}$ path had shown lower SST compared to climatology and it was beyond the standard deviation. Maximum decrease in SST was $\sim 1.5^{\circ} \mathrm{C}$ (Figure $5)$.

\section{Variation in chlorophyll-a field}

The chlorophyll distribution was from $0.13 \mathrm{mg} / \mathrm{m}^{3}$ to $0.23 \mathrm{mg} / \mathrm{m}^{3}$ in May climatology along the storm track Figure 5. $495 \mathrm{~km}$ path from $11.5^{\circ} \mathrm{N}$ to $16^{\circ} \mathrm{N}$ with low SST also showed high chlorophyll concentration comred to climatology and corresponding increased phytoankton biomass was $30 \%$ to $66 \%$ from climatology (Figure 5).

\subsubsection{Cyclonic Storm \\ Variation in SST field}

The minimum and maximum temperature was $28.9^{\circ} \mathrm{C}$ and $30.35^{\circ} \mathrm{C}$ along the storm track in the 10 years May climatology (Figure 6).

The mean SST variation in May 2002 along the storm track during May 2002 is shown in Figure 6. SST was decreased from $30^{\circ} \mathrm{C}$ to $28.75^{\circ} \mathrm{C}$ around $67^{\circ} \mathrm{E}$ to $65^{\circ} \mathrm{E}$ longitude corresponding to wind speed increased from $\mathrm{D}$ to DD [21]. But when wind speed was increased from DD to D [21] SST again increased but still that increase was lower compared to 10-year climatology value (Figure 6). Again wind speed increased [21] from $62.5^{\circ} \mathrm{E}$ longitude and SST was lowered up to $28.25^{\circ} \mathrm{C}$ (Figure 6). But whole path length around $1320 \mathrm{~km}$ was lowered compared to climatology SST (Figure 6).

The climatological May chlorophyll was ranged from $0.11 \mathrm{mg} / \mathrm{m}^{3}$ to $0.22 \mathrm{mg} / \mathrm{m}^{3}$ along the storm track (Figure 6). In May 2002 increased chlorophyll was seen 0.075 $\mathrm{mg} / \mathrm{m}^{3}$ compared to climatology value (Figure 6). From $63^{\circ} \mathrm{E}$ to $56^{\circ} \mathrm{E}$ (around $\sim 770 \mathrm{~km}$ path) of high chlorophyll compared to climatology value was seen (Figure 6).

In Arabian Sea in pre-monsoon season decrease in SST $\sim 1^{\circ} \mathrm{C}$ and increase in chlorophyll $\sim 0.132567 \mathrm{mg} / \mathrm{m}^{3}$ was observed when wind speed was increased from $\mathrm{D}$ to DD and CS and SCS (Figure 7).

\subsubsection{Pre-Monsoon Season in the Bay of Bengal}

\subsubsection{Very Severe Cyclonic Storm}

May SST 2003 showed maximum cooling of $\sim 1.5^{\circ} \mathrm{C}$ along the storm track. With lower SST $1045 \mathrm{~km}$ from $5^{\circ} \mathrm{N}$ to $14.5^{\circ} \mathrm{N}$ showed higher chlorophyll-a distribution and maximum increased chlorophyll-a $0.1 \mathrm{mg} / \mathrm{m}^{3}$ was observed from climatology. The SST and chlorophyll-a distribution was within the standard deviation of 10 years climatology in May 2004 and April 2006. 

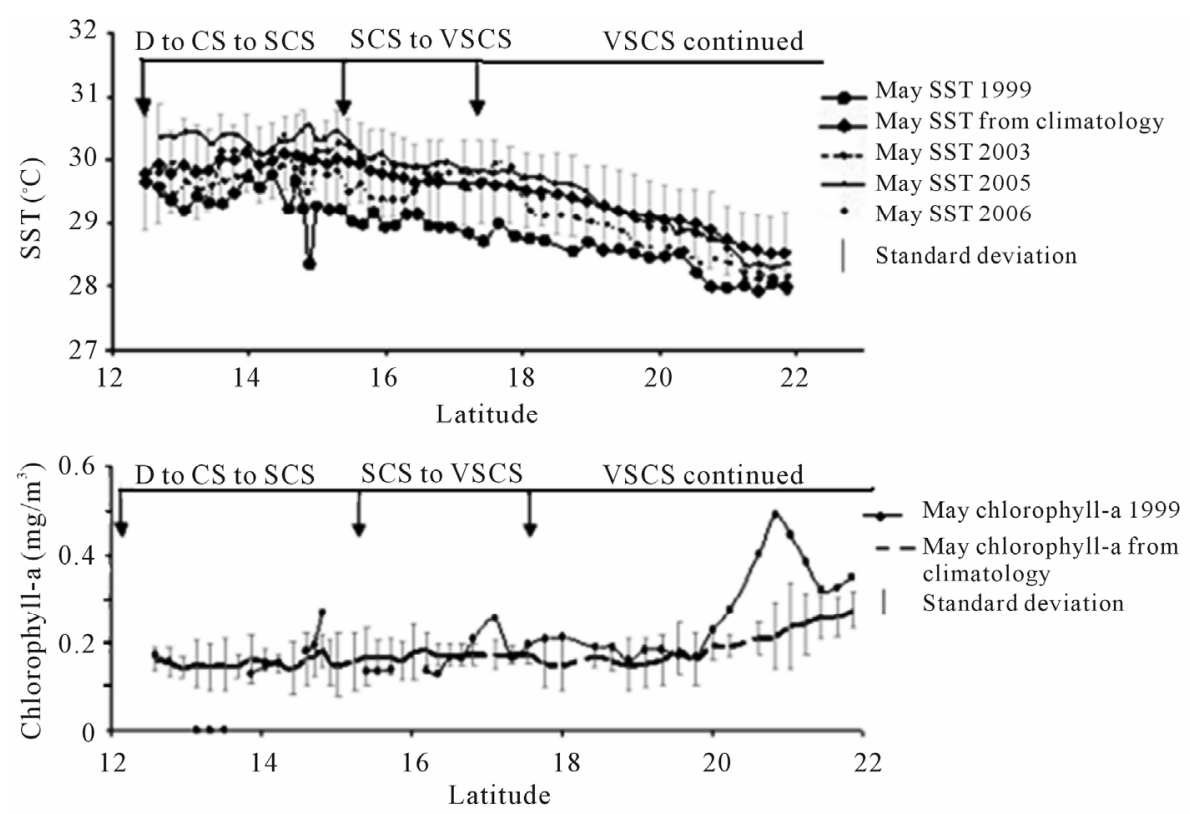

Figure 4. Mean SST and chlorophyll-a variation along the VSCS in the pre-monsoon season in the Arabian Sea.
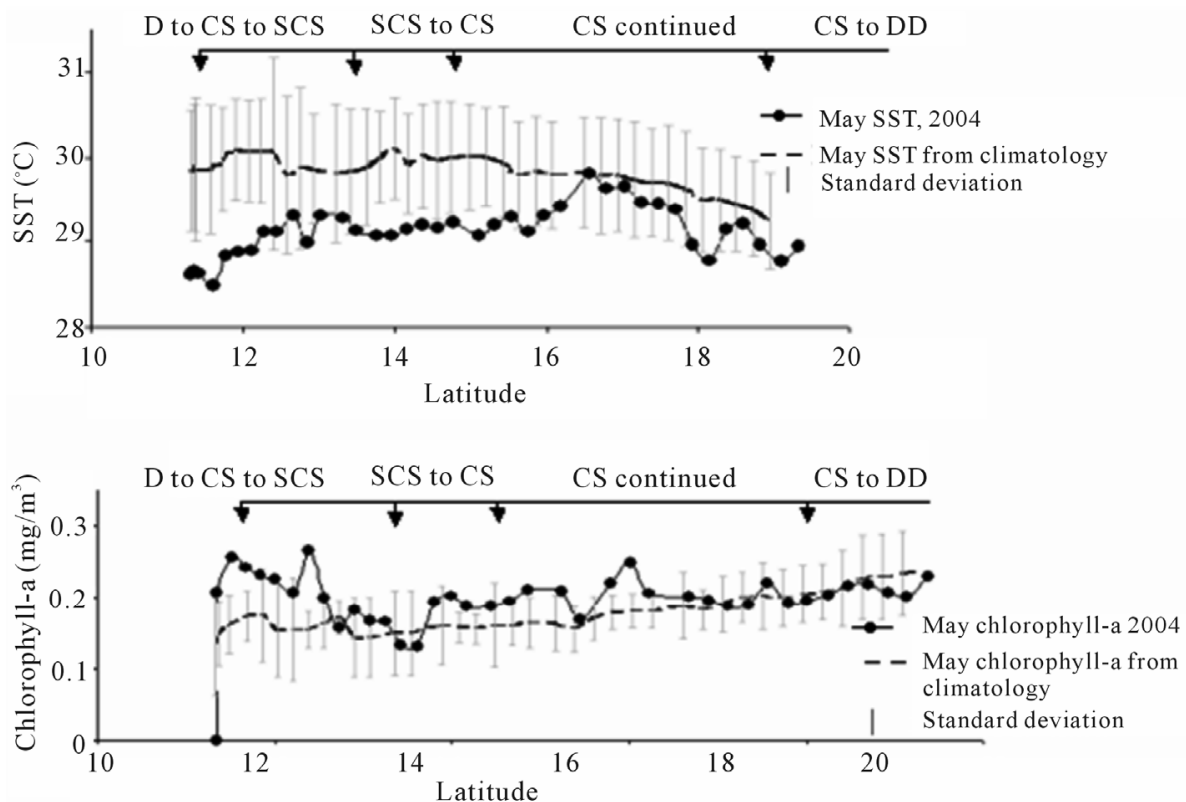

Figure 5. Mean SST and chlorophyll-a variation along the SCS in the pre-monsoon season in the Arabian Sea.

\subsubsection{Severe Cyclonic Storm}

In May month of 1998 the SST variation along the cyone track does not show any effect but the SST along the whole path was higher compared to the climatology SST. But when the wind speed increased from CS to SCS [17], higher chlorophyll-a distribution was observed from $18^{\circ} \mathrm{N}$ to $20^{\circ} \mathrm{N}$ but still the chlorophyll-a distribution was within the standard deviation.

\subsubsection{Cyclonic Storm}

The SST was lower along whole storm path compared to climatology during May 2007. Maximum decrease of SST was $\sim 1.25^{\circ} \mathrm{C}$ compared to climatology around $16.5^{\circ} \mathrm{N}$ latitude. Increased chlorophyll was observed roughly from $0.25 \mathrm{mg} / \mathrm{m}^{3}-0.4 \mathrm{mg} / \mathrm{m}^{3}$ around $18.25^{\circ} \mathrm{N}$ to $20^{\circ} \mathrm{N}$ latitude in May 2007.

\subsubsection{Post Monsoon Season in the Arabian Sea}

\subsubsection{Severe Cyclonic Storm}

Maximum decrease of $\mathrm{SST} \sim 1^{\circ} \mathrm{C}$ from $53.5^{\circ} \mathrm{E}$ to $51^{\circ} \mathrm{E}$ was observed from climatology in November 2003 where the variation of November SST climatology was from 


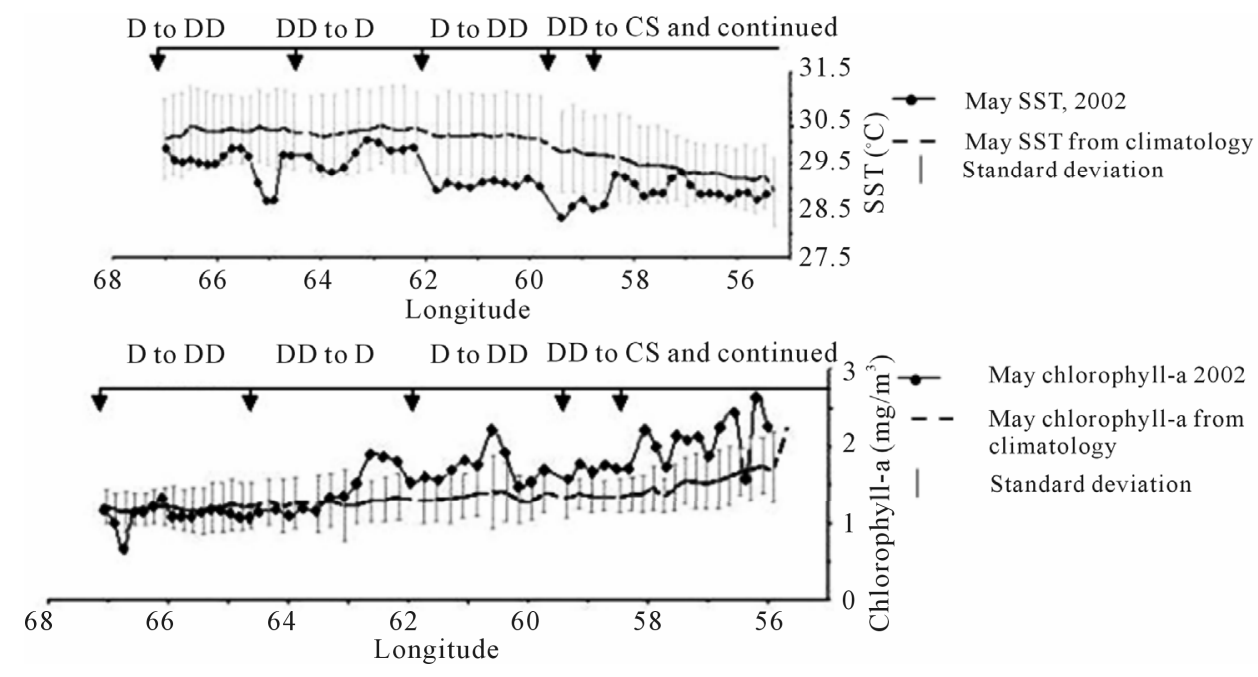

Figure 6. Mean SST and chlorophyll-a variation along the CS in the premonsoon season in the Arabian Sea.
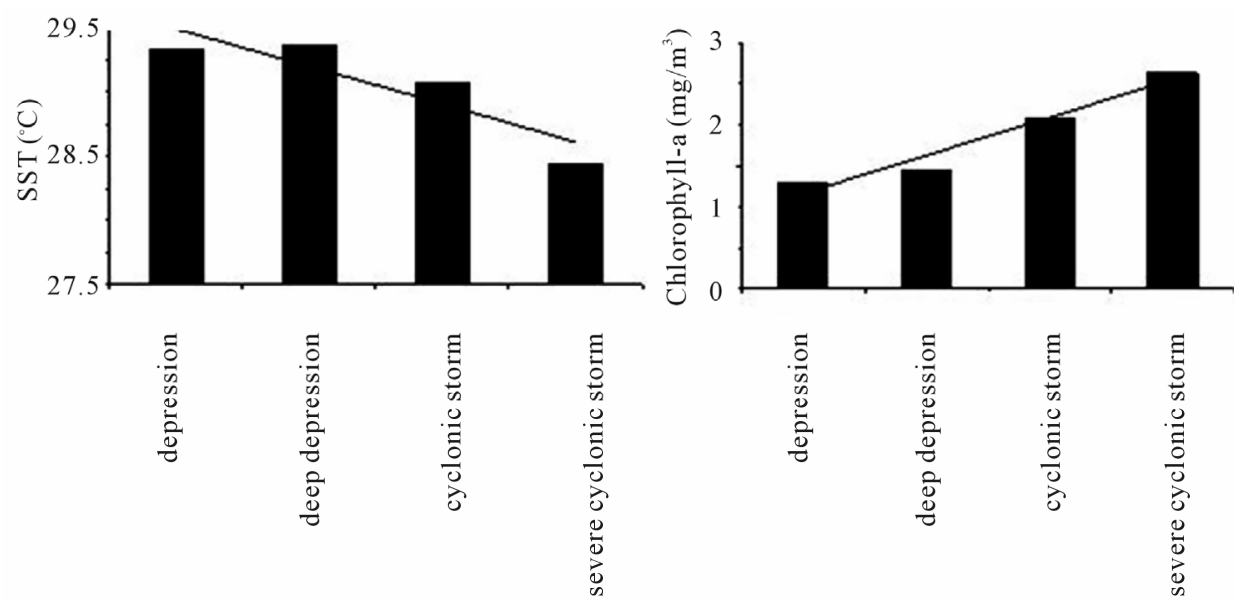

(a)

(b)

Figure 7. The effect of different stages of cyclonic events on SST (a) and chlorophyll-a (b) in the open ocean in the pre-monsoon season in the Arabian Sea.

$28.17^{\circ} \mathrm{C}$ to $29.18^{\circ} \mathrm{C}$ with mean SST was $28.56^{\circ} \mathrm{C}$ along the storm track. There were two areas from $59.5^{\circ} \mathrm{E}$ to $57.5^{\circ} \mathrm{E}$ and from $54.5^{\circ} \mathrm{E}$ to $52.5^{\circ} \mathrm{E}$ longitude in November 2003 showed high chlorophyll-a concentration compared to climatology and even that increase was beyond the standard deviation of 10 years climatology. Maximum increase of chlorophyll-a was ranged from $0.15 \mathrm{mg} / \mathrm{m}^{3}$ to $0.25 \mathrm{mg} / \mathrm{m}^{3}$ compared to climatology.

\subsubsection{Cyclonic Storm}

The SST and chlorophyll-a variation of October 1998 and October 2001 was within the standard deviation of 10 years climatology.

\subsubsection{Post Monsoon Season in the Bay of Bengal}

3.4.4.1. Super Cyclone

In October 1999 maximum decrease of SST roughly from $0.5^{\circ} \mathrm{C}$ to $2.0^{\circ} \mathrm{C}$ was observed from climatology and low SST was observed around $17.5^{\circ} \mathrm{N}$ to $20^{\circ} \mathrm{N}$ whereas high chlorophyll was observed roughly around $16.5^{\circ} \mathrm{N}$ to $18.5^{\circ} \mathrm{N}$ and Increased of chlorophyll-a was doubled from 10 years chlorophyll-a climatology.

\subsubsection{Very Severe Cyclonic Storm}

November SST 2007 did not show any affect by VSCS, but along the whole path roughly $\sim 1155 \mathrm{~km}$ November chlorophyll 2007 was higher than climatology. Maximum increase of chlorophyll was from $0.05 \mathrm{mg} / \mathrm{m}^{3}$ to 0.3 $\mathrm{mg} / \mathrm{m}^{3}$ from climatology in November 2007.

The SST and chlorophyll variation was within standard deviation of 10 years climatology in November 1998,2000 . Around $15.5^{\circ} \mathrm{N}$ latitude there were increased chlorophyll-a $\sim 0.1 \mathrm{mg} / \mathrm{m}^{3}$ was observed in November 1998. $1^{\circ} \mathrm{C}$ decrease of SST in November 2000 was observed around $81^{\circ} \mathrm{E}$ longitude. 


\subsubsection{Cyclonic Storm}

The SST and chlorophyll-a variation in October 2000 and 2001 along the cyclone track were within the standard deviation of 10 years climatology.

\subsection{Daily Analysis of SST and Chlorophyll-a and Spatial Extension of Affected SST and Chlorophyll-a}

\subsubsection{Daily Analysis of SST and Chlorophyll-a}

To understand the anomaly in SST and chlorophyll in monthly images one example of cyclonic storm in the Arabian Sea during 6-10 May 2002 was taken for daily analysis. The duration of the cyclonic storm was 6 May, 2002 to 10 May 2002 [21]. The ideal variation of wind speed from Levitus climatology was 0 - 6.5 meter/second in May month and $0-4$ meter/second in April month (Figure 8). The wind speed variation on 18 April 2002 was ranging $1-3.5$ meter/second along the storm track (Figure 8).

SST variation on $18^{\text {th }}$ April was taken as base for daily SST analysis. SST was varying from $28.4^{\circ} \mathrm{C}$ to $30.3^{\circ} \mathrm{C}$ along the storm track on $18^{\text {th }}$ April 2002.

\section{Variation in SST}

The variation of SST of 14 days before and 10 days after of cyclonic storm (during 22 April, 2002 to 22 May, 2002) across the storm path is shown in Figures 9 and 10.

The variation of SST on 22 April, 2002 and 23 April, 2002 was similar to the variation of SST of 18 April, 2002. From 24 April to 28 April higher SST compared to $18^{\text {th }}$ April, 2002 was observed. On 26 April and 27 April $3.5^{\circ} \mathrm{C}$ higher SST compared to 18 April was observed on 28 April lower SST was observed from $63^{\circ} \mathrm{E}$ to $65^{\circ} \mathrm{E}$ and 1 May onward lowering of SST was started. On 3 May maximum $4^{\circ} \mathrm{C}$ lower SST was observed. Because of heavy cloud cover during cyclone period satellite data were not available.

After cyclonic storm on 11 May $2002 \sim 2^{\circ} \mathrm{C}$ lowering of temperature was observed from $61^{\circ} \mathrm{E}$ to $55^{\circ} \mathrm{E}$. On 13 May 2002 onwards the lowering of temperature was more and after 10 days on 21 May $\sim 3^{\circ} \mathrm{C}$ low SST was observed from 18th April.

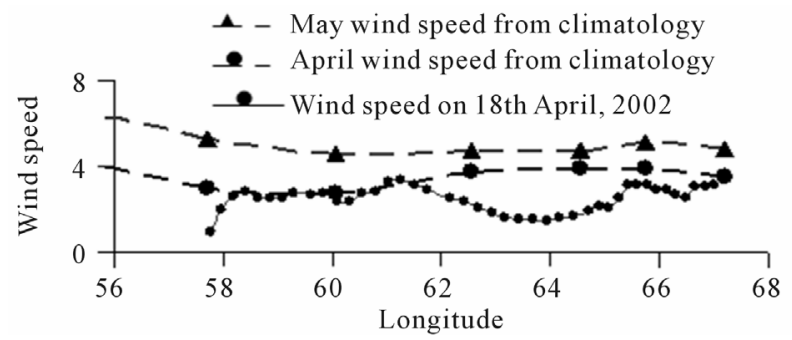

Figure 8. Wind speed of April and May month along the storm track from climatology data in the Arabian Sea. Scalar wind speed along the storm track on 18 April 2000.

\section{Variation in chlorophyll-a}

The chlorophyll-a variation during 22 April 2002 to 1 May, 2002 was varying from $0.094-0.22 \mathrm{~g} / \mathrm{m}^{3}$ across the storm track (Figure 11). The chlorophyll distribution along the storm track was averaged from 22 April to 1 May as the variation of chlorophyll was less during this period and lowering of SST started after 1 May. This averaged chlorophyll distribution from 22 April to 1 May was considered as base.

After cyclonic storm the distribution of chlorophyll during 11 May to 21 May was shown in Figure 10. On 12 May $55^{\circ} \mathrm{E}$ to $61^{\circ} \mathrm{E}$ latitude high chlorophyll was observed. Maximum $240 \%$ increased chlorophyll was observed on 20 May around $55^{\circ} \mathrm{E}$ longitude. 21 May Onward the distribution was within the average chlorophyll-a from 22 April 2002 to 1 May 2002.

\subsubsection{Special Extension of the Effect of Cyclonic Disturbances}

In order to understand how much area of the basin was affected by cyclonic storm, two examples of cyclonic disturbances in the Arabian Sea were discussed. The path of VSCS, 1999 (Figure 12(a)) was latitude wise whereas the path of CS, 2002 (Figure 12(b)) was longitude wise.

The SST and chlorophyll-a distribution right and left side of VSCS, 1999 is shown in Figures 13 and 14.

From 3 degrees right to 8 degrees left from track of VSCS, 1999 showed low SST along whole path compared to climatology. But high chlorophyll was observed from 1 degree right to 8 degrees left. The chlorophyll-a distribution in 2 degrees right and 3 degrees right from storm track was within the standard deviation (Figure 13(a)). The chlorophyll-a distribution was much higher in the left side compared to right side of the track VSCS 1999. In 7 degrees left $300 \%$ increased chlorophyll was observed compared to climatology.

Similar observation was observed in case of CS, 2002 also. From 1degree right to 7 degrees left from track of CS, 2002 showed lower SST along whole path compared to climatology. From 2 degrees right onward the SST variation was within the standard deviation. Maximum $150 \%$ increased chlorophyll was observed in two degree left from storm track of CS, 2002.

\section{Discussion and Conclusions}

Analysis of 100 years data showed that there was increasing trend of cyclonic disturbances in AS whereas there was a decreasing trend in the BOB in last decade (1998-2007).

Cyclonic disturbances caused an enhanced phytoplankton biomass in the open ocean of upper stratified water column in the BOB and the AS.

Higher cyclonic wind speed caused high phytoplankton biomass in the North Indian Ocean [10]. But only 
22 April, 2002
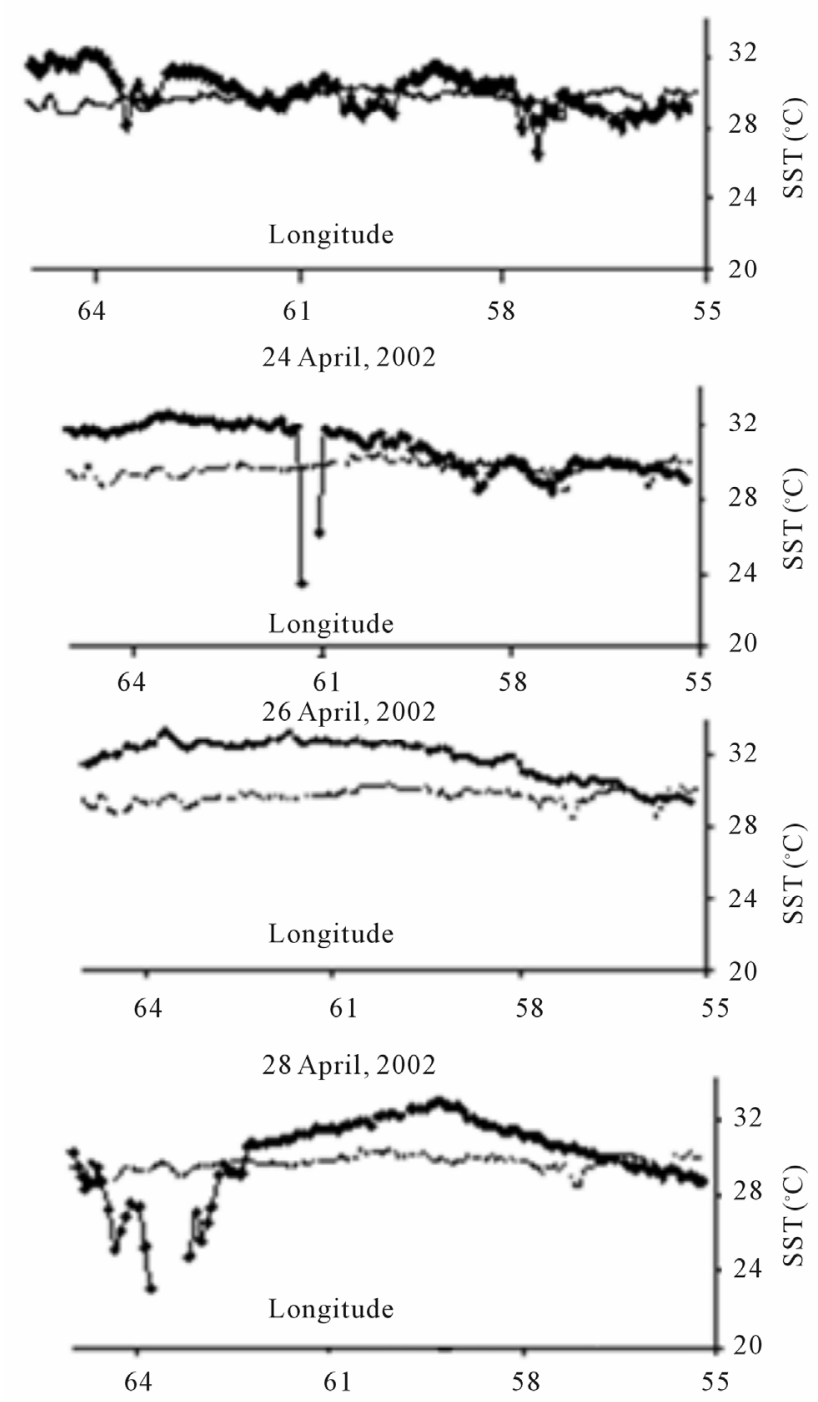

1 May, 2002

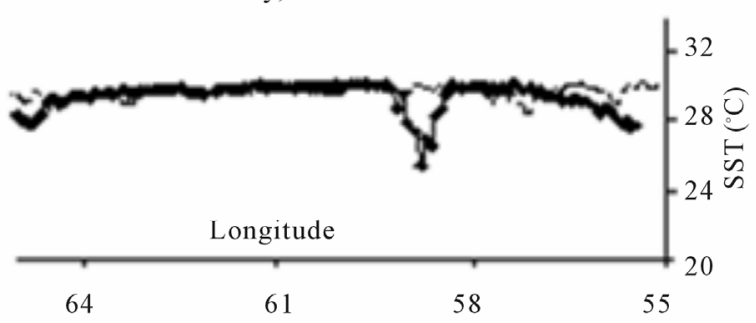

4 May, 2002

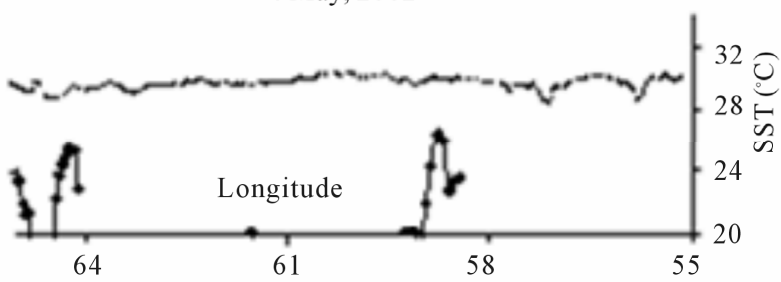

23 Apri1, 2002
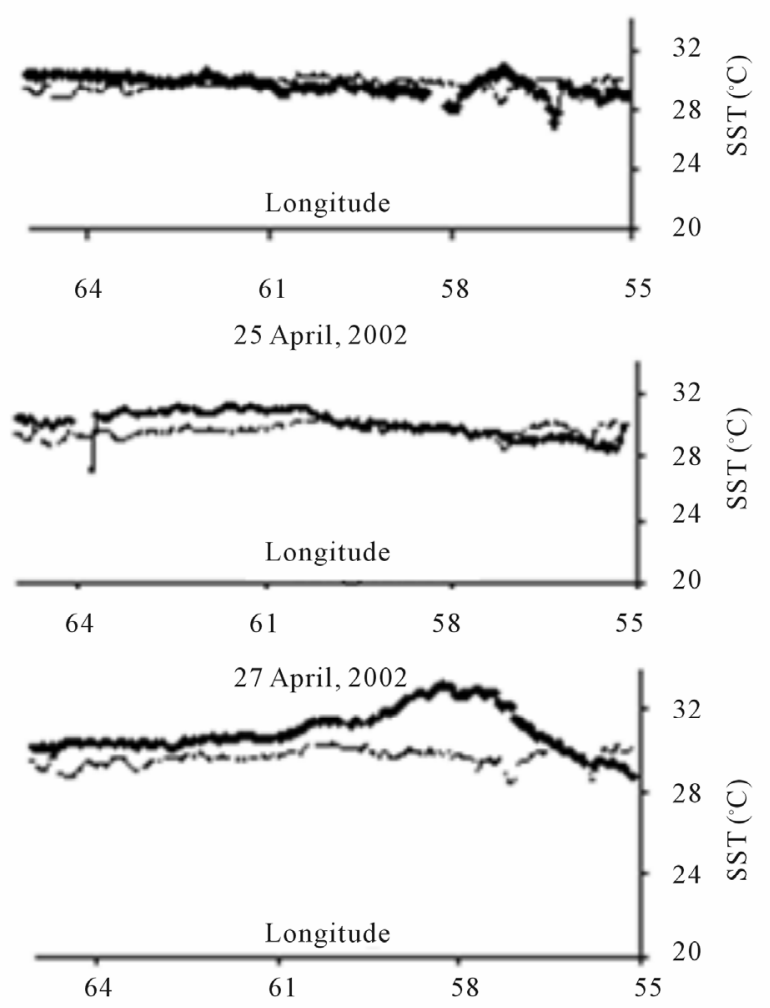

30 April, 2002

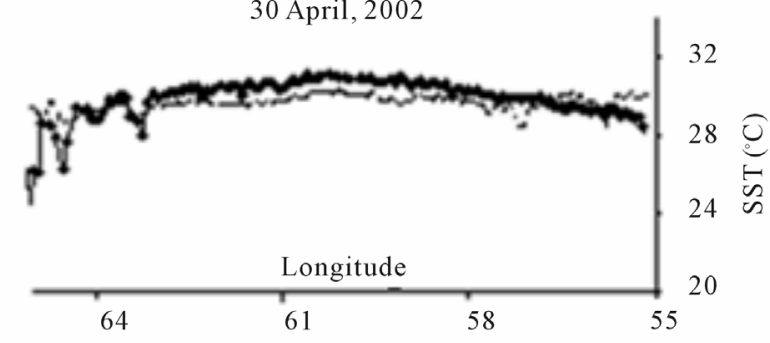

3 May, 2002

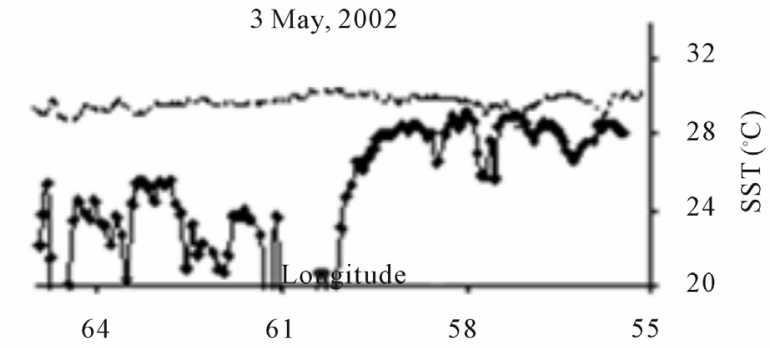
--_ SST on 18th April, 2002

Figure 9. SST variation during pre-cyclone period (from 22 April 2002 to 4 May 2002) along storm track. 


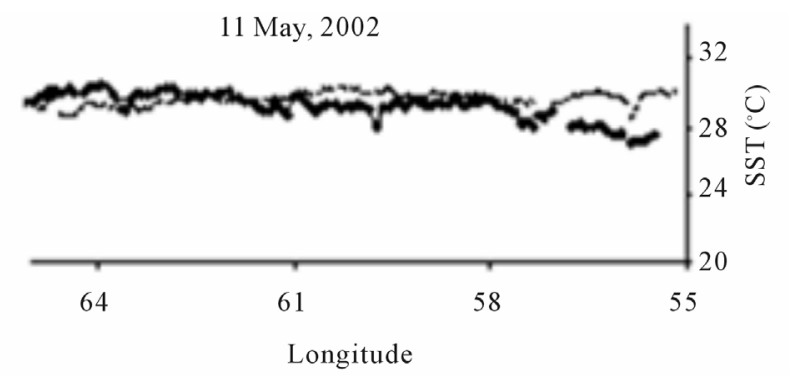

13 May, 2002
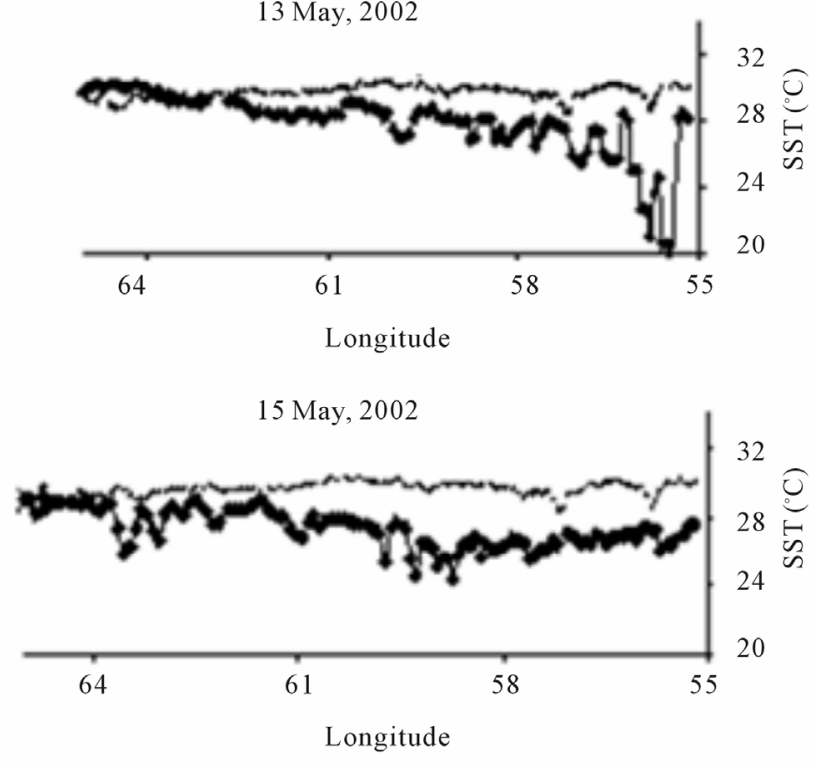

17 May, 2002
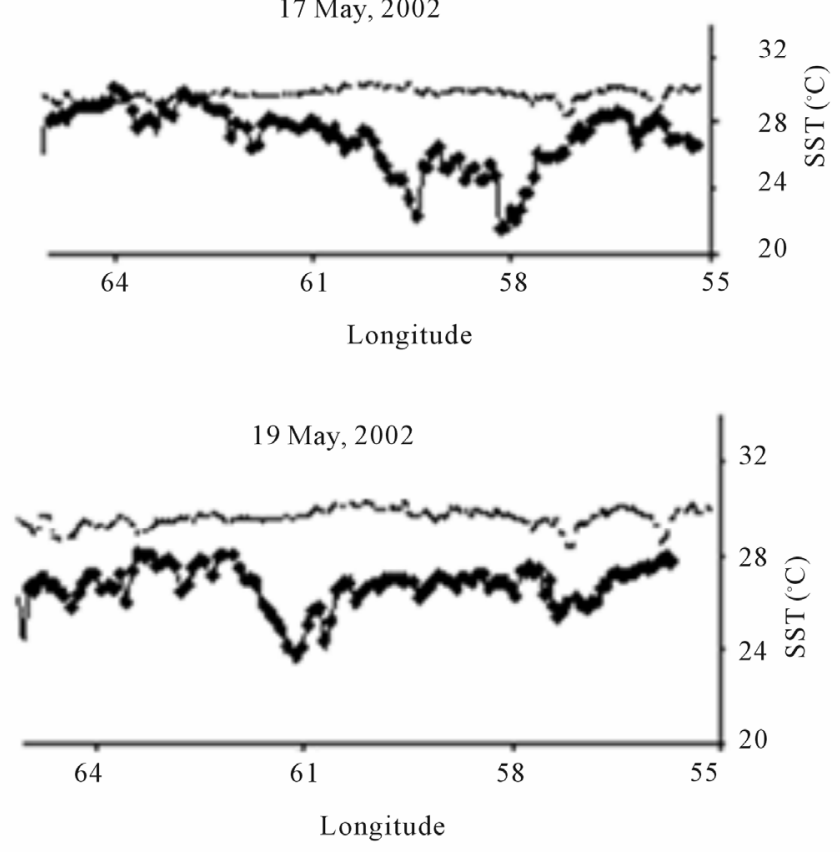

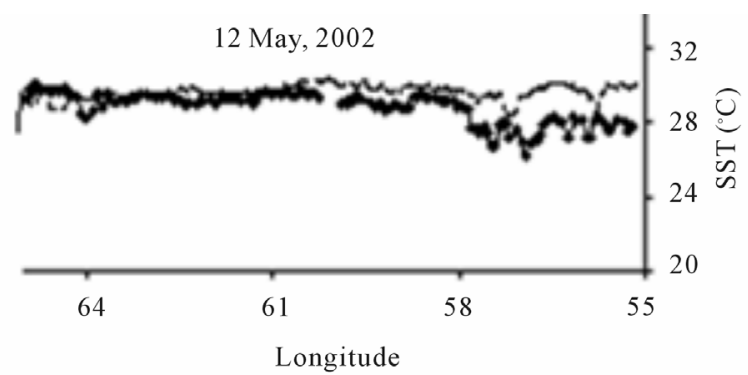

14 May, 2002

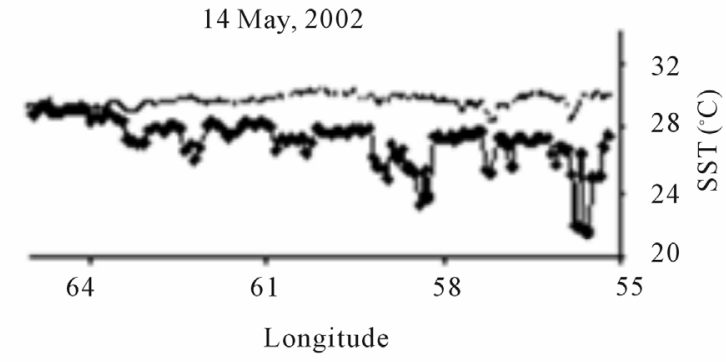

16 May, 2002

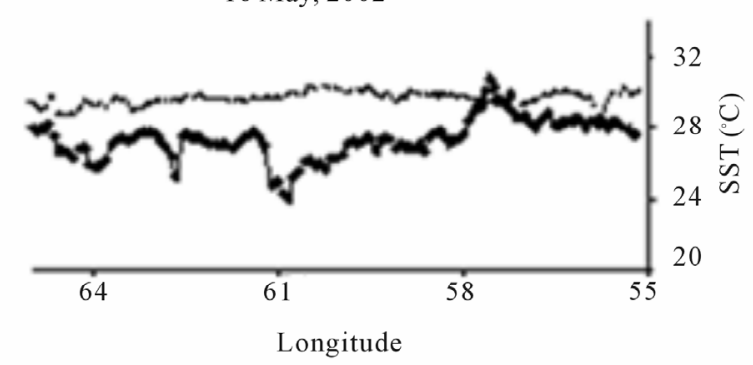

18 May, 2002
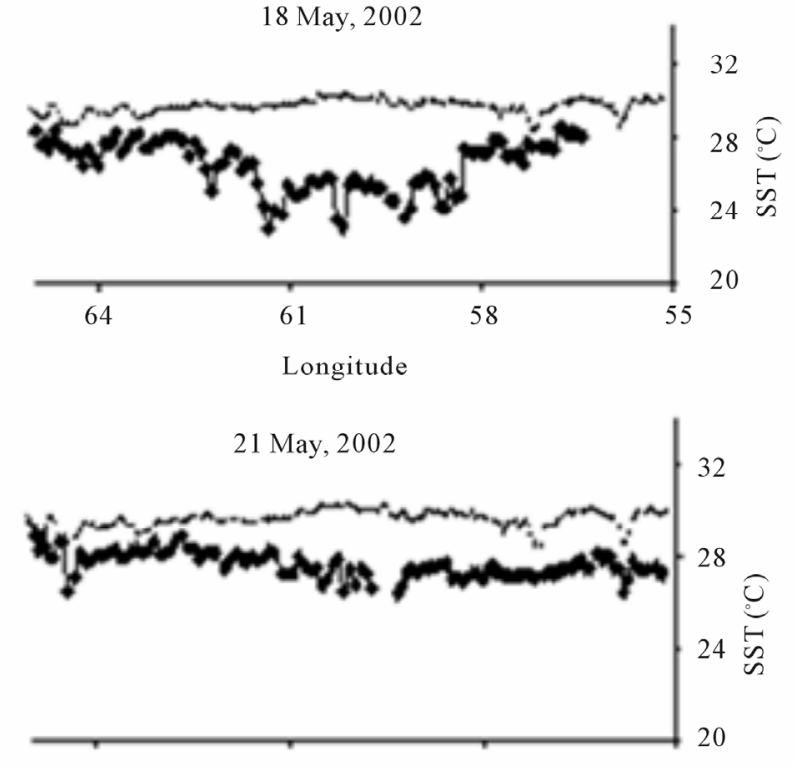

64 55

Longitude

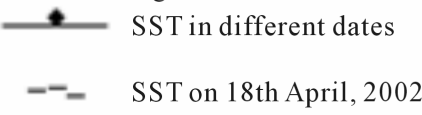

$\longleftarrow$ SST in different dates

--_ $\quad$ SST on 18th April, 2002

Figure 10. SST variation during post-cyclone period (from 11 May 2002 to 2 May 2002); (b) Along storm track. 

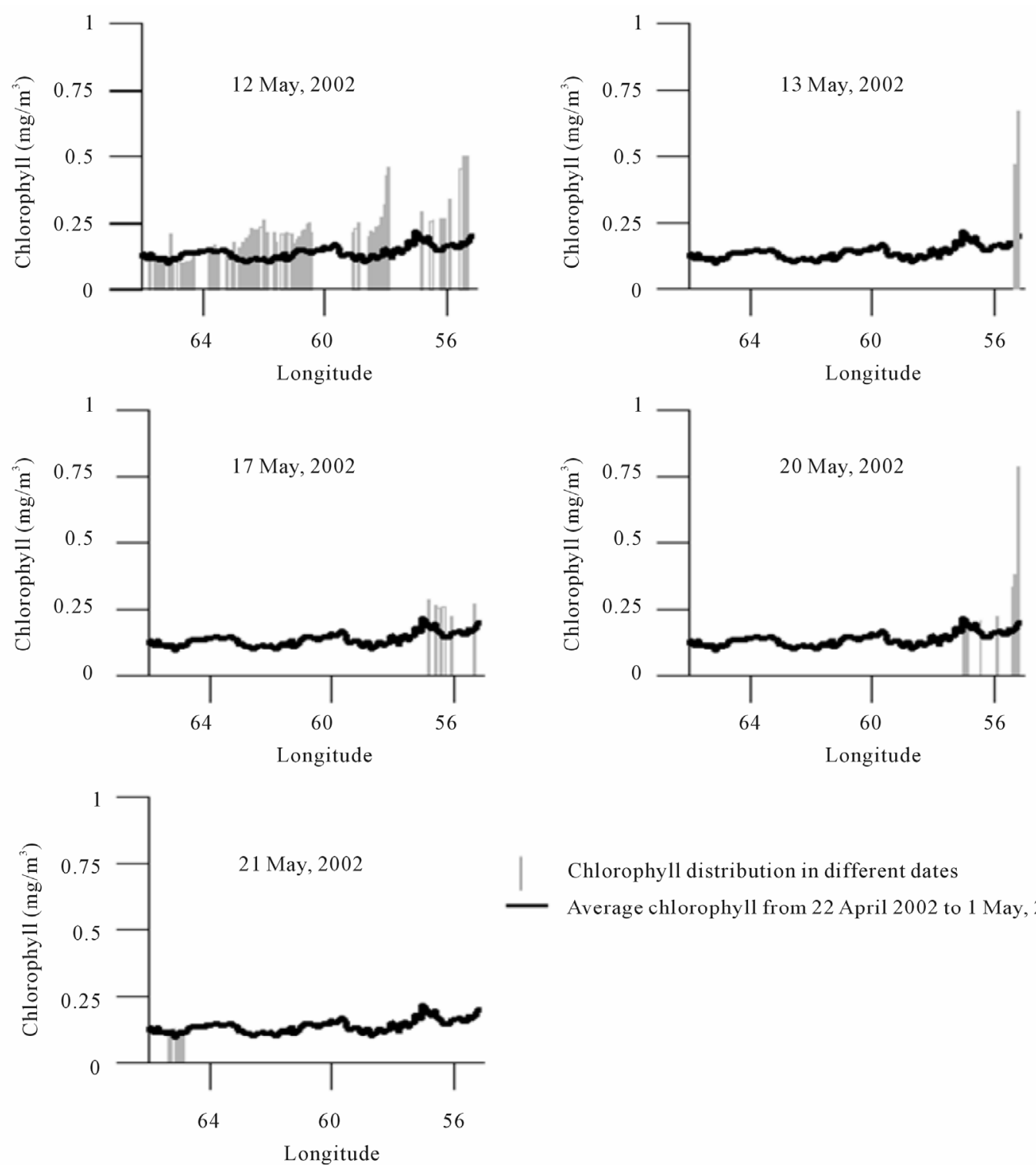

Figure 11. Chlorophyll variation during post-cyclone period (from 11 May 2002 to 21 May 2002) and comparison with average chlorophyll during 22 April, 2002 to 1 May, 2002 along storm track.

high wind speed was not sufficient reason for increased phytoplankton biomass, duration of high wind speed and path covered by the cyclonic wind also control the increased productivity pattern. For example the chlorophyll and SST variation were within the standard deviation of 10 years climatology in May 2001 in the Arabian Sea. The most probable reason was that in May 2001 cyclone wind speed increased from low pressure to very severe cyclone within 1 day and cover only $110 \mathrm{~km}$ path. Signal of the effect of cyclonic disturbances was observed in November 2003, whereas in October 1998 and October 2001 the distribution of chlorophyll-a and SST were within standard deviation in the BOB. The cyclonic wind continued only $110 \mathrm{~km}$ and $165 \mathrm{~km}$ path in October 1998 and October 2001 whereas cyclonic and severe cyclonic wind persisted $614 \mathrm{~km}$ paths in 2003 .

The cyclonic wind effects both chlorophyll and sea surface temperature distribution in both Arabian Sea and Bay of Bengal in daily scale $[9,10,12,14]$. But the decrease of SST and corresponding increased productivity pattern in both BOB and AS would be significant in climate change contest, if the daily changes in physical property would reflect in monthly chlorophyll-a and sea surface temperature distribution.

In 2000 there were no cyclonic disturbances in the pre-monsoon and post-monsoon season. It was observed that May SST 2000 was colder compared to May SST of different years. In 2007 though in May there were no cyclonic disturbances, but there was a severe cyclonic storm Gonu during 1-7 June 2007 [26] and a cyclonic 


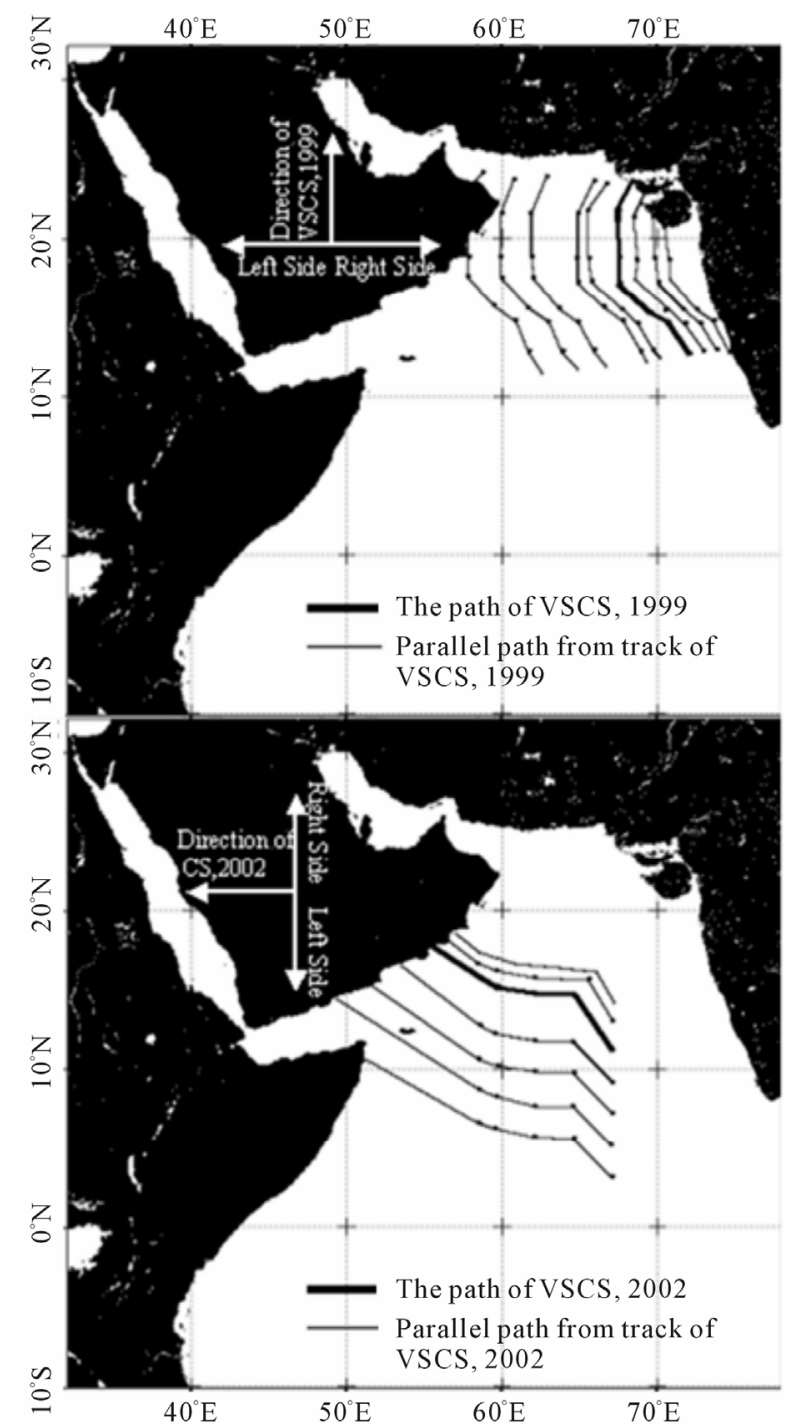

Figure 12. The path of VSCS, 1999 and parallel path from track from VSCS, 1999 (a). The path of CS, 2002 and parallel path from track of CS, 2002 (b).

storm Yemyin during 25-26 June 2007 [26] in the Arabian Sea. That is why 2000 and 2007 were excluded from non cyclonic year list.

The effect of VSCS in May 1999, CS in May 2002, SCS in May 2004 and VSCS in May 2001 in the premonsoon season in the AS was discussed. Among the four cyclonic disturbances in three cases of 1999, 2002 and 2004 the effect of cyclonic disturbances were observed in monthly image of SST and chlorophyll-a. But the effect was not seen in May 2001. In May month of 1999, 2002, 2004 the maximum decrease of SST was observed in monthly scale respectively $1.75^{\circ} \mathrm{C}, 1.5^{\circ} \mathrm{C}$, and $1.5^{\circ} \mathrm{C}$ whereas the increased of chlorophyll-a was approximately $150 \%, 66 \%$ and $66 \%$ along the storm track in the AS. The chlorophyll-a distribution also showed high chlorophyll-a distribution in the left side compared to right side.

The effect of VSCS in May 2003, CS May 2007, SCS in May 1998, VSCS May 2004, and VSCS in April 2006 in the pre-monsoon season in the $\mathrm{BOB}$ was discussed. Among five cyclonic disturbances only in 2003 and 2007 the effect of cyclonic disturbances was observed in monthly scale. In rest of the cases the variation of SST and chlorophyll was within the standard deviation of 10 years climatology. The maximum cooling of SST in May 2003 was $1.5^{\circ} \mathrm{C}$, in May 2007 was $1.25^{\circ} \mathrm{C}$ and maximum increase of chlorophyll-a was 66\% in May 2003 and abnormally high $160 \%$ in 2007 along the storm track compared to climatology was observed.

In the post monsoon season the cyclonic disturbances were having short path length in the BOB compared to premonsoon season in the AS. The effect of SCS in November 2003, CS in October 1998, and CS in October 2001 was discussed. Signal of the effect of cyclonic disturbances was observed in November 2003, whereas in October 1998 and October 2001 the distribution of chlorophyll and SST were within standard deviation. The maximum decrease of SST was observed $\sim 1^{\circ} \mathrm{C}$ and maximum $100 \%$ increase was observed in November 2003 along the storm track.

The occurrences of cyclonic disturbances and intensity were more in the BOB in post monsoon season compared to other season. During 10 years period (1998-2007) there were four D, four DD, which did not intensified in to cyclonic storm. Rather than that there were seven CS, one SCS, four VSCS and one super cyclonic storm. Among all the disturbances, the effect of cyclonic disturbance was observed in super cyclone October 1999 and VSCS November 2007. In 1999 the maximum decrease of SST was observed $2^{\circ} \mathrm{C}$ and increased phytoplankton biomass was $100 \%$ along the super cyclone track. In 2007 increased phytoplankton was $100 \%$ from climatology but SST variation does not show the effect in 2007. In rest of the cyclonic disturbances, the distribution of SST and chlorophyll was within the standard deviation of 10 years climatology.

The cause of the low SST and high productivity in the monthly scale was examined by daily scale analysis taking one example of cyclonic storm during May 2002. 12 to 7 days before there was high SST compared to climatology. Before 5 days the lowering of SST started and after 10 days of cyclonic storm lower SST compared to climatology was observed. Correspondingly high phytoplankton biomass was observed after 10 days of cyclonic storm. After cyclonic storm maximum $3{ }^{\circ} \mathrm{C}$ low SST and $240 \%$ increased phytoplankton biomass extended up to 10 days and contributed in monthly scale.

In order to understand how much area of the basin was affected by cyclonic disturbances, two examples of cyclonic disturbances in the Arabian Sea were discussed. 

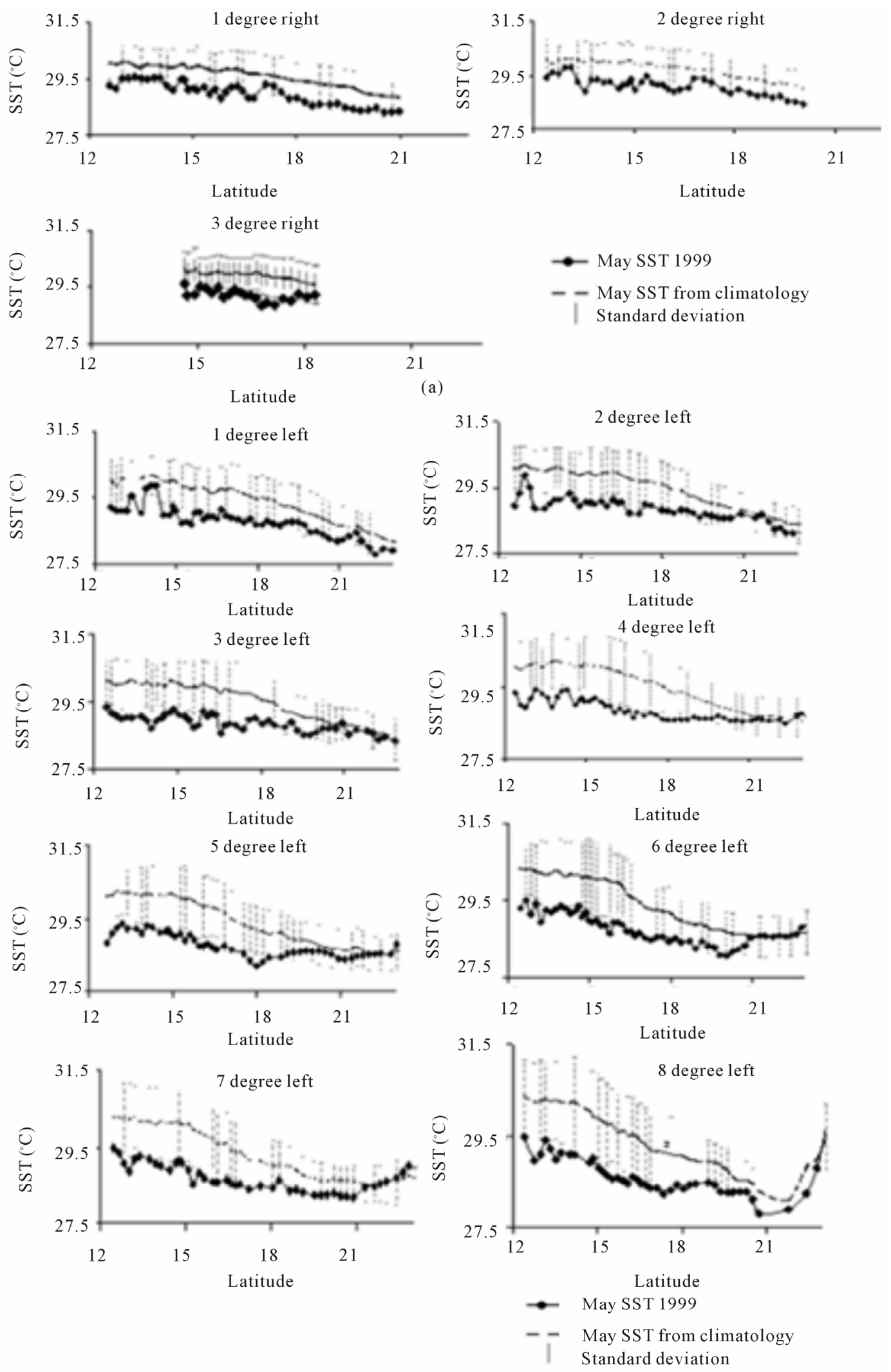

(b)

Figure 13. SST distribution right side (a) and left side (b) from storm track of VSCS, 1999. 

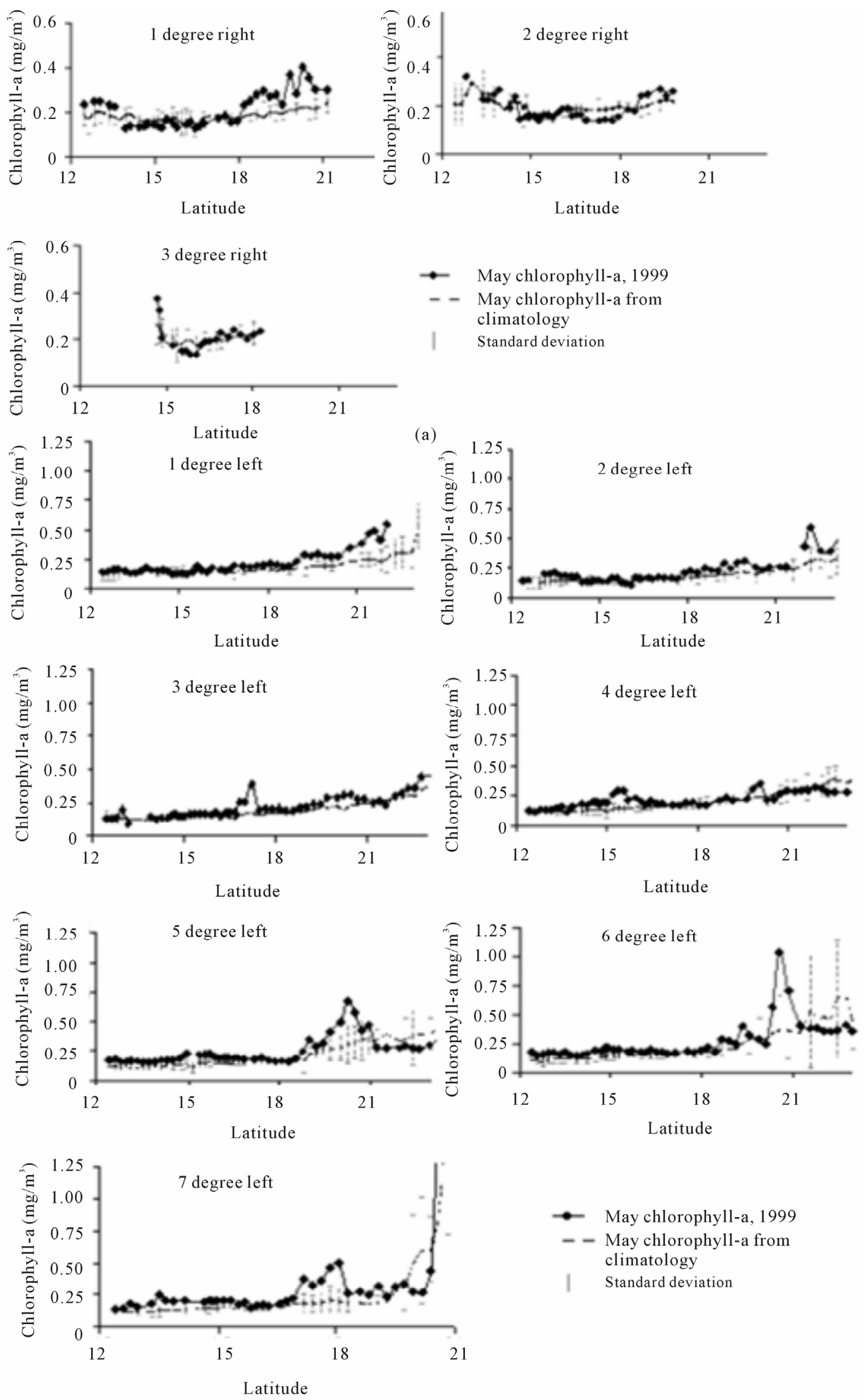

Figure 14. Chlorophyll distribution right side (a) and left side (b) from storm track of VSCS, 1999. 
The path of VSCS, 1999 was latitude wise whereas the path of CS, 2002 was longitude wise. In both the cases lower SST and higher chlorophyll distribution in the left side compared to right side from the storm track was observed.

Frequent such disturbances in the pre-monsoon and post-monsoon season can result in a changing ecological structure of the open ocean on a decadal scale in the $\mathrm{BOB}$ and AS.

\section{Acknowledgements}

The authors would also like to thank two anonymous reviewers for their critical comments and useful suggestions, which helped to improve the manuscript and also to PoDAC and other sites used for the study.

\section{REFERENCES}

[1] C. D. Hoyos, P. A. Agudelo, P. J. Webster and J. A. Curry, "Deconvolution of the Factors Contributing to the Increase in Global Hurricane Intensity," Science, Vol. 312, No. 5770, 2006, pp. 94-97. doi:10.1126/science. 1123560

[2] P. A. Agudelo and J. A. Curry, "Analysis of Spatial Distribution in Tropospheric Temperature Trends," Geophysical Research Letters, Vol. 31, No. L22207, 2004, pp. 1-5. doi:10.1029/2004GL020818

[3] Solomon, S. D. Qin, M. Manning, Z. Chen, M. Marquis, K. B. Averyt, M. Tignor and H. L. Miller, Eds., "IPCC, 2007: Summary for Policymakers," Climate Change 2007: The Physical Science Basis. Contribution of Working Group I to the 4th Assessment Report of the Intergovernmental Panel on Climate Change, Cambridge University Press, Cambridge, 2007.

[4] S. P. Kumar, P. M. Muraleedharan, T. G. Prasad, M. Gauns, N. Ramaiah, S. N. DeSouza, S. Sardessai and M. Madhupratap, "Why Is the Bay of Bengal Less Productive during Summer Monsoon Compared to the Arabian Sea?" Geophysical Research Letter, Vol. 29, No. 24, 2002, pp. 1-17.

[5] D. A. Mooley and C. M. Mohile, " Cyclonic Storms of the Arabian Sea, 1877-1980," Mausam, Vol. 35, No. 2, 1984, pp. 127-134.

[6] S. P. Kumar, R. P. Roshin, J. Narvekar, P. K. D. Kumar and E. Vivekanandan, "Response of the Arabian Sea to Global Warming and Associated Regional Climate Shift," Marine Environmental Research, Vol. 68, No. 5, 2009, pp. 217-222. doi:10.1016/j.marenvres.2009.06.010

[7] P. J. Webster, G. J. Holland, J. A. Curry and H. R. Chang, "Changes in Tropical Cyclone Number, Duration, and Intensity in a Warming Environment," Science, Vol. 309, No. 5742, 2005, pp. 1844-1846. doi:10.1126/science. 1116448

[8] J. F. Price, "Upper Ocean Response to a Hurricane," Journal of Physical Oceanography, Vol. 11, No. 2, 1981, pp. 153-175. doi:10.1175/152004858(1981)011<0153:UORTAH $>2.0$. $\mathrm{CO} ; 2$
[9] S. N. Kundu, A. K. Sahoo, S. Mohapatra and R. P. Singh, "Change Analysis Using IRS-P4 OCM Data after the Orissa Super Cyclone," International Journal of Remote Sensing, Vol. 22, No. 7, 2001, pp. 1383-1389. doi:10.1080/01431160119932

[10] B. Subrahmanyam, K. H. Rao, N. S. Rao and V. S. N. Murty, "Influence of a Tropical Cyclone on Chlorophyll-a Concentration in the Arabian Sea," Geophysical Research Letters, Vol. 29, No. 22, 2002, pp. 1-22. doi:10.1029/2002GL015892

[11] R. Gautam, R. P. Singh and M. Kafatos, "Changes in Ocean Properties Associated with Hurricane Isabel," International Journal of Remote Sensing, Vol. 26, No. 3, 2005, pp. 643-649. doi:10.1080/01431160412331299226

[12] K. H. Rao, A. Smitha and M. M. Ali, "A Study on Cyclone Induced Productivity in South-Western Bay of Bengal during November-December 2000 Using MODIS (SST and Chlorophyll-a) and Altimeter Sea Surface Height Observations," Indian Journal of Marine Sciences, Vol. 35, No. 2, 2006, pp. 153-160.

[13] M. M. Gierach and B. Subrahmanyam, "Satellite Data Analysis of the Upper Ocean Response to Hurricanes Katrina and Rita (2005) in the Gulf of Mexico," IEEE Geoscience and Remote Sensing Letters, Vol. 4, No. 1, 2007, pp. 132-136. doi:10.1109/LGRS.2006.887145

[14] S. K. Tummala, R. S. Mupparthy, N. M. Kumar and S. R. Nayak, "Phytoplankton Bloom Due to Cyclone Sidr in the central Bay of Bengal," Journal of Applied Remote Sensing, Vol. 3, No. 1, 2009, pp. 1-14. doi:10.1117/1.3238329

[15] S. Karmakar, "The Impact of Tropical Cyclones on the Coastal Regions of SAARC Countries and Their Influence in the Region," 1st Edition, SAARC Meteorological Research Centre (SMRC), Sumit Printing Press, Bangladesh, 1998.

[16] S. K. Dikshit, D. S. Desai and V. Krishnan, "Cyclones and Depressions over Indian Seas and Neighbourhood during 1997," Mausam, Vol. 49, No. 3, 1998, pp. 279284.

[17] V. Thapiyal, D. S. Desai and V. Krishnan, "Cyclones and Depressions over North Indian Ocean during 1998," Mausam, Vol. 50, No. 3, 1999, pp. 233-242.

[18] V. Thapiyal, D. S. Desai and V. Krishnan, "Cyclones and Depressions over North Indian Ocean during 1999," Mausam, Vol. 51, No. 3, 2000, pp. 215-224.

[19] V. Thapiyal, D. S. Desai and V. Krishnan, "Cyclones and Depressions over North Indian Ocean during 2000," Mausam, Vol. 52, No. 3, 2001, pp. 455-462.

[20] V. Thapiyal, A. B. Mazumder and V. Krishnan, "Cyclones and Depressions over North Indian Ocean during 2001," Mausam, Vol. 53, No. 3, 2002, pp. 265-270.

[21] V. Thapiyal, A. B. Mazumdar and S. Sunitha, "Cyclones and Depressions over North Indian Ocean during 2002," Mausam, Vol. 54, No. 3, 2003, pp. 579-584.

[22] N. Jayanthi, A. B. Mazumdar and S. S. Devi, "Cyclones and Depressions over North Indian Ocean during 2003," Mausam, Vol. 55, No. 3, 2004, pp. 389-396.

[23] N. Jayanthi, A. B. Mazumdar and S. S. Devi, "Cyclones 
and Depressions over North Indian Ocean during 2004," Mausam, Vol. 56, No. 3, 2005, pp. 517-526.

[24] N. Jayanthi, R. R. Lele and S. S. Devi, "Cyclones and Depressions over the North Indian Ocean during 2005," Mausam, Vol. 57, No. 3, 2006, pp. 379-394.

[25] A. B. Mazumdar, R. R. Lele and S. S. Devi, "Cyclones and Depressions over North Indian Ocean during 2006," Mausam, Vol. 58, No. 3, 2007, pp. 305-322.
[26] A. B. Mazumder, M. Khole and S. S. Devi, "Cyclones and Depressions over North Indian Ocean during 2007," Mausam, Vol. 59, No. 3, 2008, pp. 273-290.

[27] J. E. O'Reilly, S. Maritorena, B. G. Mitchell, B. G. Mitchell, D. A. Siegel, K. L. Carder, S. A. Garver, M. Kahru and C. McClain, "Ocean Color Chlorophyll Algorithms for SeaWiFs," Journal of Geophysical Research, Vol. 103, No. C11, 1998, pp. 24937-24953. 